\title{
Material Control and Accounting Design Considerations for High- Temperature Gas Reactors
}

\author{
Trond Bjornard \\ John Hockert
}

August 2011
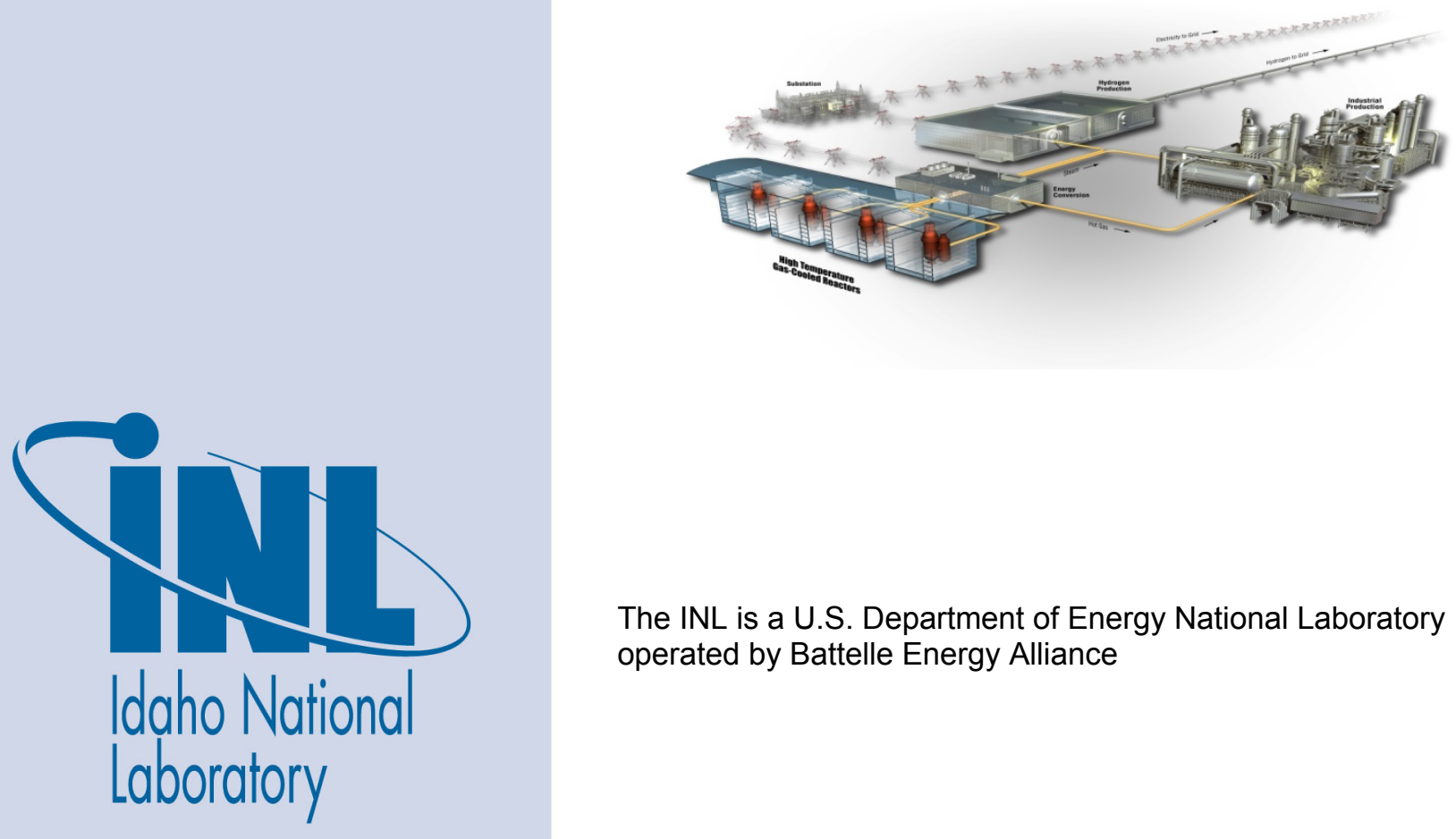

The INL is a U.S. Department of Energy National Laboratory operated by Battelle Energy Alliance 


\section{DISCLAIMER}

This information was prepared as an account of work sponsored by an agency of the U.S. Government. Neither the U.S. Government nor any agency thereof, nor any of their employees, makes any warranty, expressed or implied, or assumes any legal liability or responsibility for the accuracy, completeness, or usefulness, of any information, apparatus, product, or process disclosed, or represents that its use would not infringe privately owned rights. References herein to any specific commercial product, process, or service by trade name, trade mark, manufacturer, or otherwise, does not necessarily constitute or imply its endorsement, recommendation, or favoring by the U.S. Government or any agency thereof. The views and opinions of authors expressed herein do not necessarily state or reflect those of the U.S. Government or any agency thereof. 


\title{
Material Control and Accounting Design Considerations for High-Temperature Gas Reactors
}

\author{
Trond Bjornard \\ John Hockert
}

August 2011

\begin{abstract}
Idaho National Laboratory
Fuel Cycle Research and Development

Idaho Falls, Idaho 83415
\end{abstract}

http://www.inl.gov

Prepared for the

U.S. Department of Energy

Office of Nuclear Energy

Under DOE Idaho Operations Office

Contract DE-AC07-05ID14517 


\section{EXECUTIVE SUMMARY}

The Next Generation Nuclear Plant (NGNP) project was authorized by the Energy Policy Act of 2005 with the principal objective of designing, licensing, and building a Generation IV nuclear plant capable of producing both hightemperature process heat and electricity. The two candidate NGNP reactor concepts are pebble- and prismatic-fueled high-temperature gas reactors that will be licensed by the U.S. Nuclear Regulatory Commission (NRC).

In October 2008 the NRC issued a "Policy Statement on the Regulation of Advanced Reactors" that calls for consideration of physical protection and nuclear material control and accountability (MC\&A) during the design phase, concurrent with safety. This concept has become known by the phrase "safeguards and security by design," or 2SBD, which has both international and domestic components. The relevant domestic components for the NGNP project are MC\&A and physical protection as regulated by the NRC.

Under the 2SBD concept, MC\&A and physical protection are considered from the very beginning of the project, starting with the early formation of a design team and incorporation at the earliest project phase of relevant requirements into the formal project structure. The expected benefits of $2 \mathrm{SBD}$ are reduction of risks to project cost and schedule by avoiding the late introduction of MC\&A and physical security into the project, which sometimes requires expensive redesign or retrofit, and taking advantage of intrinsic design possibilities to make the facility more easily and cost effectively safeguarded and protected.

This report is intended to be useful to the NGNP design teams in incorporating MC\&A considerations into the plant design process. Because there are no existing NRC regulations or guidance that specifically apply to the NGNP gas reactors, the authors have adapted and interpreted existing NRC regulations, guidance, and precedence to formulate suggested approaches for MC\&A that they believe would likely be acceptable to the NRC. The authors have also identified an approach to design methodology for MC\&A and have identified specific design features that should be considered in the design process for MC\&A. 


\section{CONTENTS}

EXECUTIVE SUMMARY iii

ACRONYMS vii

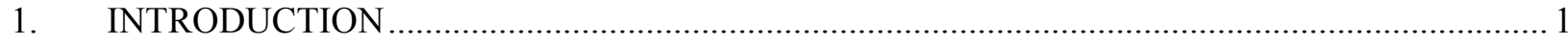

1.1 Overview of the Next Generation Nuclear Plant Project ....................................................... 1

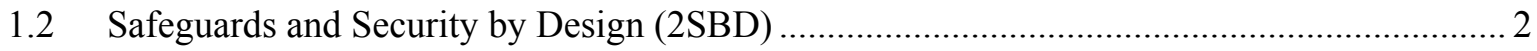

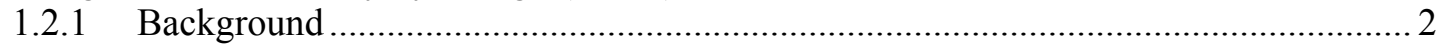

1.2.2 Safeguards and Security by Design Process (Domestic) - Motivation and

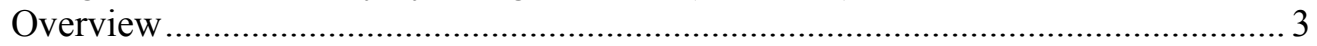

1.2.3 General HTGR Characteristics Relevant to MC\&A and Physical Protection ............ 4

1.2.4 A Possible MC\&A Design Analysis Approach ............................................................. 5

2. OVERVIEW OF THE PEBBLE-BED AND PRISMATIC-FUELED HIGH

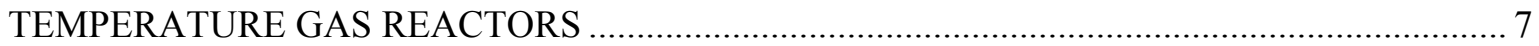

2.1 Pebble Bed HTGR, Fuel, Fuel Handling and Storage ........................................................ 7

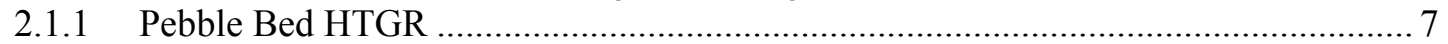

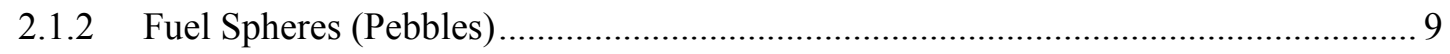

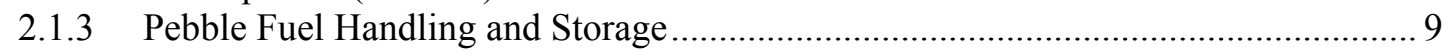

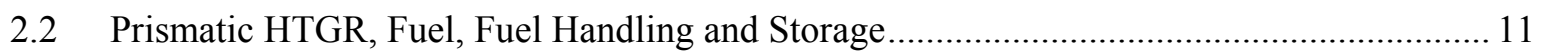

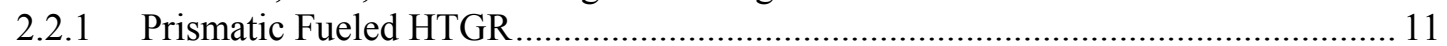

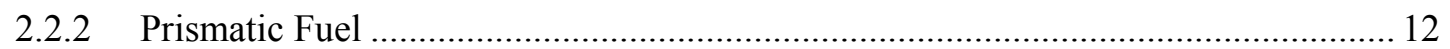

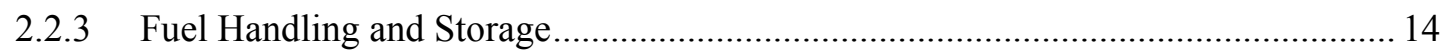

3. ANALYSIS AND INTERPRETATION OF RELEVANT NRC REGULATIONS AND

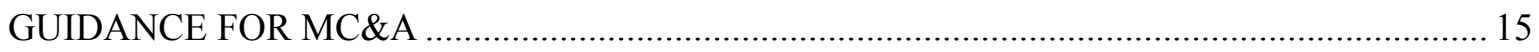

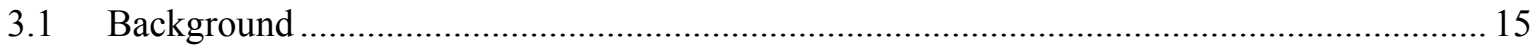

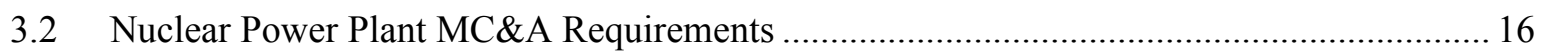

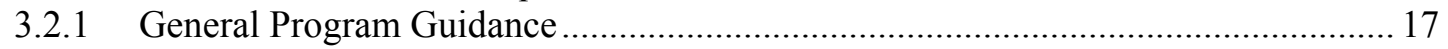

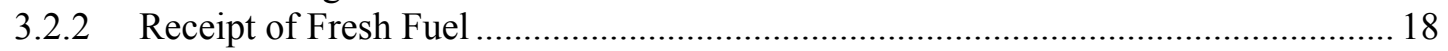

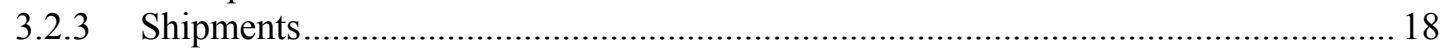

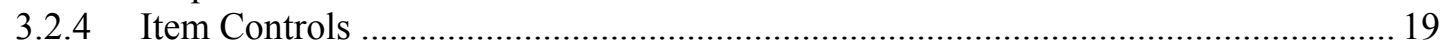

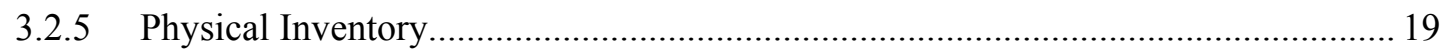

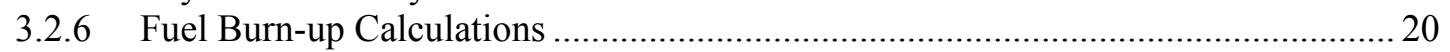

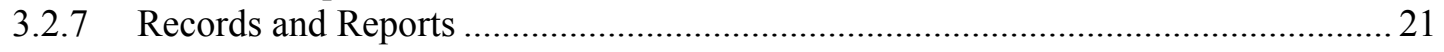

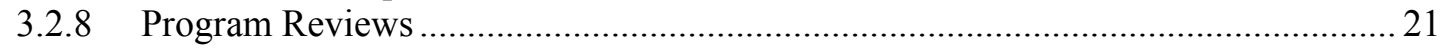

3.3 Adaptation to Reactors Other than Light Water Reactors.................................................. 21

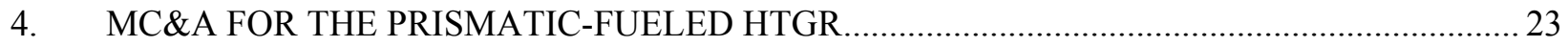

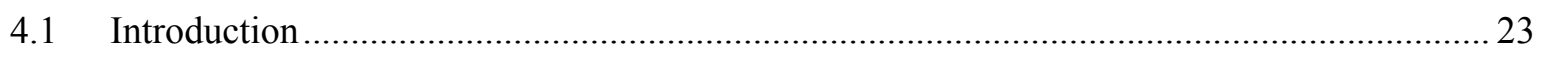

4.2 Essential Elements of Prismatic-Fueled HTGR MC\&A Program ....................................... 23

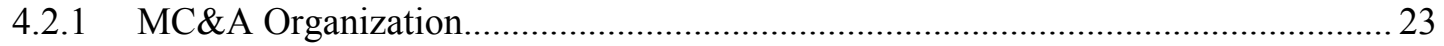

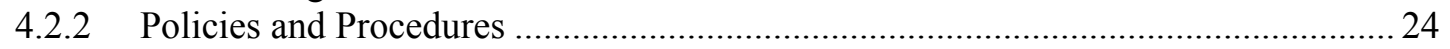

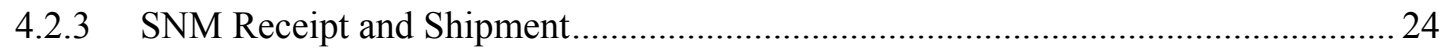

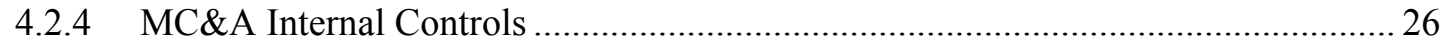

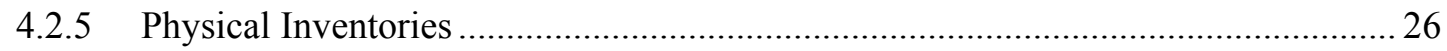

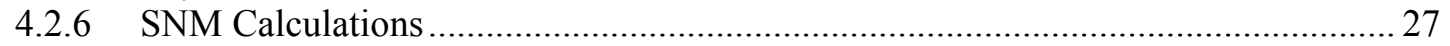




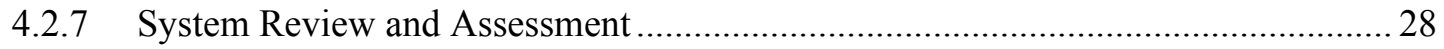

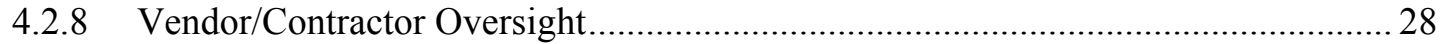

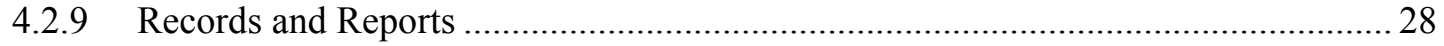

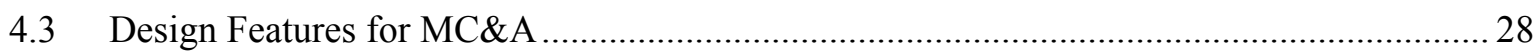

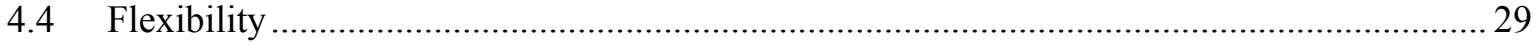

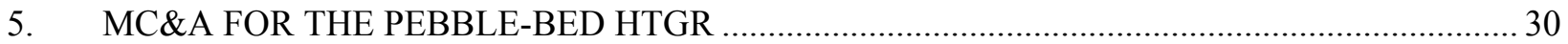

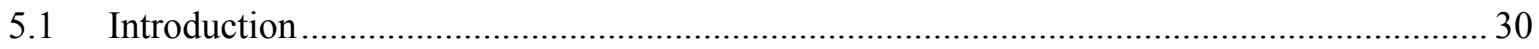

5.2 Essential Elements of Pebble-bed HTGR MC\&A Program …......................................... 30

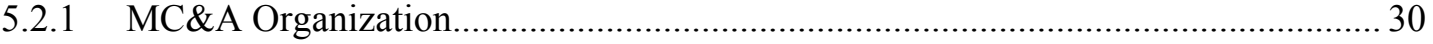

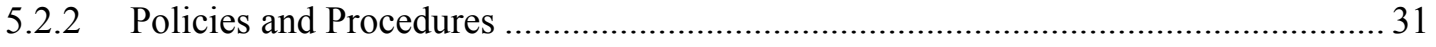

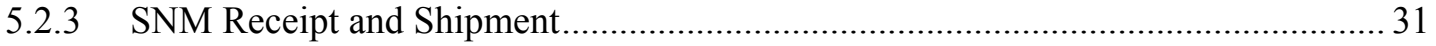

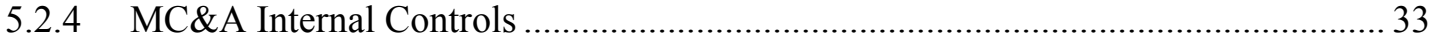

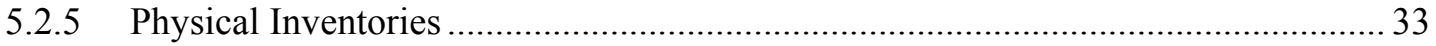

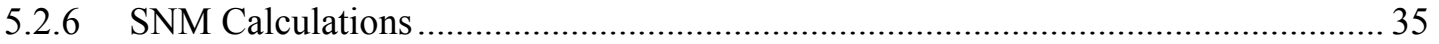

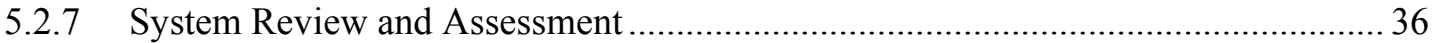

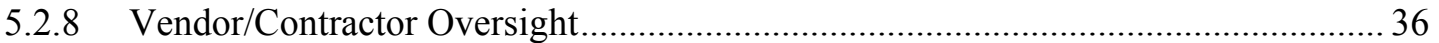

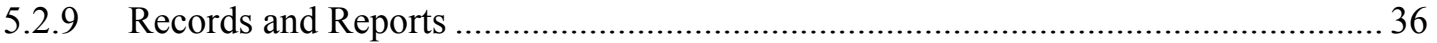

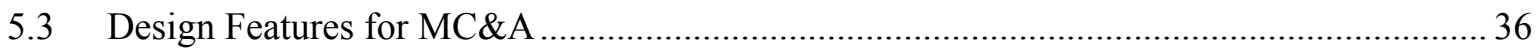

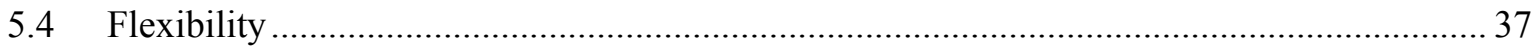

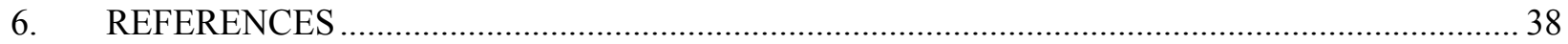

Appendix A—NRC MC\&A Regulations for Nuclear Power Reactors …............................................. 41

Appendix B —-International Safeguards MBA Layouts for HTGRs .................................................... 49

\section{FIGURES}

Figure 1. Schematic of the AREVA HTR-Module pebble-bed reactor unit............................................ 8

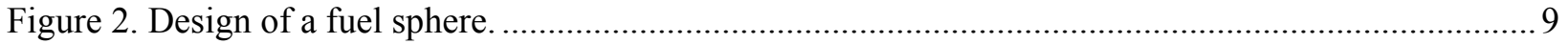

Figure 3. PBMR fuel-handling and storage system overview (normal operation). ${ }^{16}$................................ 10

Figure 4. Westinghouse PBMR fuel-handling and storage system...................................................... 11

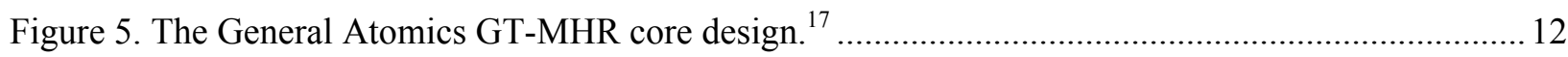

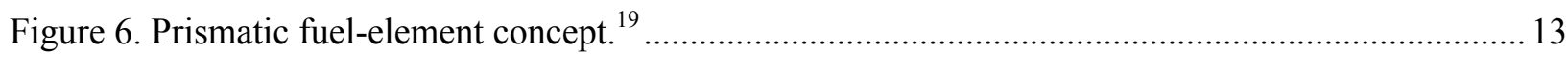

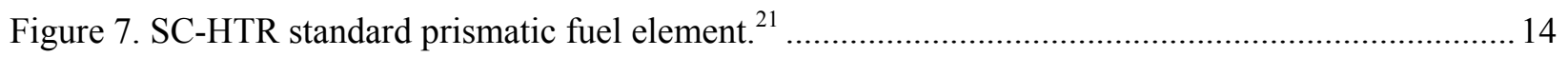

Figure B-1. Material balance area layout for a prismatic fuel HTGR. ${ }^{6}$............................................... 51

Figure B-2. Material balance area layout for pebble-fuel HTGR. ${ }^{7}$..................................................... 52 


\section{ACRONYMS}

2SBD safeguards and security by design

3SBD safeguards, security, and safety by design

AEC Atomic Energy Commission

ALARA as low as reasonably achievable

$\mathrm{CO} \quad$ carbon monoxide

DOE Department of Energy

DOE-NE Department of Energy - Office of Nuclear Energy

EPACT U.S. Energy Policy Act of 2005

FCR\&D Fuel Cycle Research and Development (program)

FNMCP Fundamental Nuclear Material Control Plan

FSV Fort St. Vrain

GA General Atomics

GT-MHR gas-turbine modular helium reactor

HTGR high-temperature gas-cooled reactor

HTR-10 10-MWt High Temperature Gas-Cooled Reactor (China)

IAEA International Atomic Energy Agency

ICA Inventory Control Area (usually used in context of item accounting)

INL Idaho National Laboratory

LEU low-enriched uranium

LWR light water reactor

MBA material balance area (usually used in context of bulk material accounting)

MC\&A Material Control and Accounting

MHTGR modular high-temperature gas-cooled reactor

MPACT Material Protection, Control, and Accountancy Technology

NEAC Nuclear Energy Advisory Committee

NGNP Next Generation Nuclear Plant

NGSI Next Generation Safeguards Initiative

NIS Office of Nonproliferation and International Security (of the National Nuclear Security Administration [NNSA])

NRC Nuclear Regulatory Commission

NSCQ Nuclear Security Concern Quantity

PBMR Pebble-Bed Modular Reactor

R\&D research and development

RFID radio-frequency identification 
SBD Safeguards by Design

SC-MHR Steam Cycle Modular Helium Reactor

$\mathrm{SiC} \quad$ silicon carbide

SNM special nuclear material

TRISO tristructural isotropic 


\section{Material Control and Accounting Design Considerations for High-Temperature Gas Reactors}

\section{INTRODUCTION}

The subject of this report is domestic safeguards and security by design (2SBD) for high-temperature gas reactors, focusing on material control and accountability (MC\&A). The motivation for the report is to provide 2SBD support to the Next Generation Nuclear Plant (NGNP) project, which was launched by Congress in 2005. This introductory section will provide some background on the NGNP project and an overview of the 2SBD concept. The remaining chapters focus specifically on design aspects of the candidate high-temperature gas reactors (HTGRs) relevant to MC\&A, Nuclear Regulatory Commission (NRC) requirements, and proposed MC\&A approaches for the two major HTGR reactor types: pebble bed and prismatic. Of the prismatic type, two candidates are under consideration: (1) GA's GT-MHR (Gas Turbine-Modular Helium Reactor), and (2) the Modular High-Temperature Reactor (M-HTR), a derivative of Areva's Antares reactor.

The future of the pebble-bed modular reactor (PBMR) for NGNP is uncertain, as the PBMR consortium partners (Westinghouse, PBMR [Pty] and The Shaw Group) were unable to agree on the path forward for NGNP during 2010. ${ }^{1}$ However, during the technology assessment of the conceptual design phase (Phase 1) of the NGNP project, AREVA provided design information and technology assessment of their pebble-bed-fueled plant design called the HTR-Module concept. AREVA does not intend to pursue this design for NGNP, preferring instead a modular reactor based on the prismatic Antares concept. Since MC\&A relevant design information is available for both pebble concepts, the pebble-bed HTGRs considered in this report are:

- Westinghouse PBMR

- AREVA HTR-Module.

The DOE Office of Nuclear Energy (DOE-NE) sponsors the Fuel Cycle Research and Development program (FCR\&D), which contains an element specifically focused on the domestic (or state) aspects of SBD. This Material Protection, Control and Accountancy Technology (MPACT) program supports the present work summarized in this report, namely the development of guidance to support the consideration of MC\&A in the design of both pebble-bed and prismatic-fueled HTGRs. The objective is to identify and incorporate design features into the facility design that will cost effectively aid in making MC\&A more effective and efficient, with minimum impact on operations.

\subsection{Overview of the Next Generation Nuclear Plant Project}

The U.S. Energy Policy Act of 2005 (EPACT-2005) established the NGNP project, the purpose of which is to design, license, construct and operate a Generation IV reactor that would produce electricity or hydrogen, or both. Idaho National Laboratory (INL) was selected as the lead laboratory for the cost-shared project between the U.S. Department of Energy (DOE) and industrial partners, and the technology chosen for development is the HTGR. Three industry consortia participated in the NGNP pre-conceptual design phase, led by the following companies: General Atomics (GA), Areva, and Westinghouse. This was followed by NGNP Phase 1, completed in 2011, which included technology assessment and selection, the conduct of enabling research and development (R\&D), and the development of an initial conceptual design for the prototype plant (a conceptual design report was completed in December 2010). Only the GA consortium (which also includes General Dynamics, URS Washington, Korea Atomic Energy Research Institute, and Fuji) participated formally in Phase 1. Phase 2 of the NGNP project will commence pending a review of Phase 1 by the Nuclear Energy Advisory Committee (NEAC) 
and a subsequent decision by the U.S. Secretary of Energy to proceed. Phase 2 is currently foreseen to competitively develop a detailed preliminary design, including licensing, on a schedule to support initial operation of the plant in 2021.

The NGNP plant will be licensed by the U.S. NRC, which issued in October 2008 the "Policy Statement on the Regulation of Advanced Reactors". ${ }^{2}$ This policy statement includes new items to be considered during the design of advanced reactors - security (concurrently with safety), the threat of theft, and international safeguards. The authors interpret the policy as promoting consideration during advanced reactor designs of MC\&A (a key element to deter nuclear material theft and provide assurance that theft prevention measures have been effective), physical protection, safety, and international safeguards. AREVA has labeled this concept 3SBD, for safeguards, security, and safety by design. ${ }^{3}$

Also in October of 2008, the International Atomic Energy Agency (IAEA) hosted an international workshop to explore a concept that has now come to be known as Safeguards by Design (SBD). Further, DOE's National Nuclear Security Administration (NNSA)-Office of Nonproliferation and International Security (NIS) launched a project in 2007 to develop the concept of SBD. ${ }^{5}$ This has blossomed into a broader SBD program under the NIS's Next Generation Safeguards Initiative (NGSI), which among other things seeks to make SBD a global norm for future nuclear facilities. In summary, there are numerous reasons to consider both the international and domestic aspects of safeguards and security (called 2SBD) in the design of new nuclear facilities, including the NGNP plant, and there are a number of programs supporting this approach.

\subsection{Safeguards and Security by Design (2SBD)}

\subsubsection{Background}

Safeguards and Security by Design includes both international and domestic (state) components. The NGSI program is concerned with the international safeguards, and two recent publications sponsored by NGSI contain international safeguards guidance for both pebble-bed and prismatic-fueled HTGRs. ${ }^{6,7}$ The present work focuses on the domestic components-MC\&A and physical protection-which for the NGNP plant are regulated by the NRC.

The IAEA's definition of SBD is "an approach whereby international safeguards are fully integrated into the design process of a nuclear facility - from initial planning through design, construction, operation, and decommissioning...The disciplined application of project management and systems engineering principles is important to the successful implementation of efficient and effective safeguards, as is its integration with other disciplines such as process design and safety."4 The domestic corollary to international SBD is "an approach whereby domestic safeguards (or MC\&A) and physical protection are fully integrated into the design process of a nuclear facility - from initial planning through design and construction." This has come to be referred to as 2SBD. It is important to emphasize that the authors promote the consideration of ALL project requirements from the earliest project stages in a single and fully integrated project, and safeguards and security are but two components of the overall project. 2SBD must be viewed in that context.

This report concerns itself with domestic safeguards by design, or MC\&A by design, for both NGNP reactor concepts, both prismatic- and pebble-fueled. The following sections describe the fuel and plant design features relevant to safeguards, the relevant NRC regulations and their interpretation for these reactor types, proposed approaches for the implementation of MC\&A, and the identification of opportunities to make MC\&A more efficient and effective through facility design. Section 1.2.2 will address the safeguards and security design (2SBD) design process. 


\subsubsection{Safeguards and Security by Design Process (Domestic) - Motivation and Overview}

When most of the U.S. commercial nuclear power plants were built several decades ago, the defined threats against nuclear facilities were very modest compared to the design basis threat (DBT) statements of the current, post-9/11 threat environment. ${ }^{8}$ The substantial increase in threat in recent years has required the U.S. nuclear industry to invest in substantial and expensive security upgrades for existing, operating nuclear power plants. Since the facilities had already been sited and built, the only practical upgrades were security system additions or upgrades and increases in protective force staffing and capabilities - for obvious reasons, most plant layout and other civil engineering options were largely precluded. The Nuclear Energy Institute (NEI), a U.S. commercial nuclear industry trade organization, reports that as of October 2004 the U.S. commercial nuclear power industry had already spent over \$1 billion since $9 / 11$ on security upgrades. These were introduced in the form of increased protective force manpower (increased by $60 \%$ to an average of 77 protective force per reactor) and capital improvements. ${ }^{9,10}$ That amount has substantially increased since then. This historical example demonstrates the high potential cost of security upgrades to facilities if the design basis threat increases after construction and there is a limited security margin to offset the threat increase. A further motivation to consider safeguards and security fully from the very beginning of the design project is to minimize the project risks in cost and schedule associated with late and non-optimal introduction of MC\&A and physical security features into the design. Further, many argue that facilities with strong intrinsic security and minimal reliance on human intervention inherently possess greater margin to accommodate future threat increases and/or changes.

The principal functions of domestic safeguards (MC\&A) are to protect against theft of nuclear materials, diversion of nuclear materials, and illicit production of nuclear materials (facility misuse) by insider and/or outsider adversaries (non-state actors only). The primary objectives are to: ${ }^{11}$

- Maintain control over the nuclear material

- Maintain accurate, timely, complete, and reliable information on the locations, quantities, and characteristics of nuclear material

- Provide for prompt investigation and resolution of nuclear material anomalies

- Provide information useful to the recovery of missing material

- Assist in detecting misuse of nuclear material handling equipment

- Act as a deterrent by providing the capability to detect insider activities related to nuclear material.

Note that the latter three functions support physical security directly. Further, in the event that a U.S. commercial nuclear facility is selected for the application of international safeguards under the U.S. Voluntary Offer Agreement with the IAEA, the MC\&A system is the basis for the facility's nuclear material declarations that must be regularly provided to the IAEA. Physical protection defends against theft of nuclear materials (fissile and radioactive) and facility sabotage. Although sabotage generally includes destruction or interruption of facility operation, the NRC requirements mandate protection against radiological sabotage, which is defined to be "any deliberate act directed against a plant or transport in which an activity licensed pursuant to the regulations in this chapter is conducted, or against a component of such a plant or transport which could directly or indirectly endanger the public health and safety by exposure to radiation." There is considerable overlap in the threats addressed by both the MC\&A and physical protection systems, and there are scenarios of theft by insider(s) where an integrated mitigation strategy that includes both MC\&A and physical protection systems working together can be more effective. For these reasons, it is important that the design process for MC\&A and physical protection involve close coordination between these disciplines and others of relevance such as operations and safety. ${ }^{12,13,14,15,16}$ Recent work proposes that MC\&A and physical protection should be analyzed 
together during the design process to evaluate all possible scenarios of theft and sabotage and ensure that the integrated systems for detection, delay, and response are optimally designed. ${ }^{11,13,16}$ Design for sabotage protection should be coordinated with facility safety design and analysis to ensure that physical protection design takes maximal advantage of facility safety features.

The design and construction process for a new nuclear facility is very much a requirements-driven process that utilizes project management and systems engineering to ensure that the resulting facility optimally fulfills its mission-while meeting all requirements. Because of the deep rigor of the systems engineering discipline (which includes requirements tracking and change control), attention to a relatively small number of basic principles in the design process is recommended to ensure realizing the full potential benefit of the consideration of safeguards and security during design. ${ }^{12,16}$ The basic principles are:

- Establishment and full involvement of the safeguards and security design team from the very beginning of the project (note that some of the earliest project decisions, such as facility siting, can have immense impact on intrinsic facility security).

- Adequate and formal empowerment of the safeguards and security design team within the formal project structure (this should include specific authorizations under the project organization's quality assurance manual).

- Early identification of MC\&A and physical protection requirements and their early inclusion in the formal project requirements document.

- Frequent regulatory review and approval of MC\&A and security design approaches as the design progresses and at all key decision points.

- Early and repeated scenario analysis to identify intrinsic design features that will cost-effectively benefit the MC\&A and security performance of the facility, with re-analysis as design detail evolves. (Some major performance benefits associated with site selection, site topography, layout, and other civil engineering options can only be economically achieved very early in the design process.)

\subsubsection{General HTGR Characteristics Relevant to MC\&A and Physical Protection}

Physical protection is often thought of as involving three major activities: detection, delay, and response. Recent work on the topic of security by design ${ }^{16,17}$ suggests considering physical protection in terms of five major activities: design, devalue, detection, delay, and response. Design is added to reflect the importance of early attention to physical protection in the design process in order to reap the benefits of cost-effective, intrinsic design features beneficial to security. Devalue refers to designing a facility to make it a less valuable target for an adversary. A number of intrinsic characteristics of the NGNP HTGRs make them relatively unattractive targets for both radiological sabotage and nuclear material theft:

- The tri-structural isotropic (TRISO) fuel particles embedded in graphite moderator have very high melting temperatures and are mechanically robust.

- The negative temperature coefficient of reactivity shuts the reactor down if it overheats.

- The single-phase gas coolant, high core heat capacity, radiative core cooling capability, high melting temperatures, and high heat capacity of the core matrix allow the reactors to survive loss of forced cooling without core melting and without release of radioactivity.

- The fuel is low-enrichment U-235, or LEU (less than $8 \%$ enrichment in the pebble fuel, less than $20 \%$ enrichment in the prismatic fuel), which is contained in small TRISO particles distributed within bulky graphite moderator. It takes a very large volume of fuel to obtain $9 \mathrm{~kg}$ of U-235 (about 18700 pebbles in the case of the PBMR, which the authors believe will be NRC's quantity of interest for nuclear material accountancy purposes in the PBMR). 
According to the applicable NRC regulations contained in 10CFR Part 73, "Physical Protection of Plants and Materials," the pebble fuel (less than 8\% enrichment) is considered to be special nuclear material (SNM) of low strategic significance, sometimes referred to as a Category III quantity of material. NRC regulations define the prismatic HTGR fuel (somewhat less than 20\% enrichment) to be "special nuclear material of moderate strategic significance," sometimes referred to as a Category II quantity of material. The NRC uses a graded approach to the control and protection of nuclear material, where the degree of protection varies according to the attractiveness and quantity of nuclear material concerned. The applicable MC\&A requirements for the NGNP HTGRs are discussed in Section 3.

\subsubsection{A Possible MC\&A Design Analysis Approach}

As will be seen in Section 3, the NRC requirements for MC\&A in the NGNP HTGRs do not specify the type of analysis that should be performed in designing the MC\&A system for the HTGRs. There are several recent publications that address suggested analyses to aid in MC\&A system design. The design approach suggested in Reference 12 applies to both physical protection and MC\&A, as well as international safeguards, and illustrates the connection of the MC\&A and security design process with the overall facility design process. The approach proposed in Reference 11 was specifically designed for MC\&A systems analysis with emphasis on integration with security, and the major steps are:

- Identify the nuclear material detection quantity of interest

- Develop all feasible adversary scenarios based on the applicable threat statement

- Develop scenario and response timeliness

- Identify scenarios that require additional MC\&A measures for timely response

- Identify additional MC\&A measures to improve response or eliminate scenario completion

- Determine requirements for each element of the MC\&A system

- Implement the measures that achieve adversary interruption before completion

- Conduct performance testing.

Most if not all existing physical protection evaluation (vulnerability assessment) tools do not consider the interaction between MC\&A and security systems. The work discussed in Reference 16 includes discussion of an approach to include both MC\&A and physical protection in an integral fashion. Such an approach would be especially useful for time-critical scenarios in a facility processing high-value nuclear material; however, it is not clear that the low attractiveness and bulky fuel forms of the HTGRs warrant such a degree of scrutiny. In fact, the physical protection focus for the design of nuclear power plants employing LEU fuel, is sabotage protection, with adequate physical protection for theft typically achieved as a residual benefit of the security measures established for sabotage protection.

Design or procedural options that can improve MC\&A system effectiveness include: ${ }^{11,16}$

- Additional technical measures (e.g., tamper-safing devices, motion detectors, radiation monitors, automated analysis of images from surveillance)

- Redundant records systems that are cross checked periodically (e.g., manual records are compared against computerized records from fuel-handling equipment)

- Enhanced sampling plans, more frequent inventory taking

- Entry and exit controls and alarms

- Addition of exit delay (especially for short timeline scenarios)

- Redundant overcheck of shipping documents, radiation monitoring of containers 
- Special procedures to enhance control during non-routine operations (e.g., emergencies).

Ultimately, the MC\&A design team is responsible for developing and implementing a cost-effective approach that meets requirements while minimizing impact on operations. 


\section{OVERVIEW OF THE PEBBLE-BED AND PRISMATIC-FUELED HIGH TEMPERATURE GAS REACTORS}

This section discusses the specific pebble-bed and prismatic reactor and fuel designs and their fuel handling and storage systems as relevant to issues of safeguards and security. Sections 2.1 and 2.2 address the specific aspects associated with the pebble and prismatic designs, respectively.

\subsection{Pebble Bed HTGR, Fuel, Fuel Handling and Storage}

This section addresses MC\&A relevant design characteristics of the pebble-bed reactor, the fuel spheres, and fuel handling and storage provisions.

\subsubsection{Pebble Bed HTGR}

The starting point for the AREVA pebble-bed reactor core is the German HTR-Modular design, and details are likely to change as AREVA develops the concept further. This is nominally a dual-unit plant with a total power of $400 \mathrm{MWt}$. Figure 1 shows a cutaway of the reactor unit. Of particular interest to this report are the fuel charging and fuel discharge systems (the latter is portrayed in Figure 3), which are employed in online refueling. The fuel pebbles enter the top of the core and are removed through the discharge system continuously during operation. The core contains approximately 400,000 fuel spheres that each pass through the core a total of 15 times until they reach their target discharge burnup.

The 400 MWt Westinghouse PBMR is conceptually similar; however, there are three fuel feed lines at the top of the reactor and three de-fueling chutes at the bottom. ${ }^{18}$ The core nominally contains 452,000 fuel spheres that each recycle through the core 6 times until they reach target burnup. 


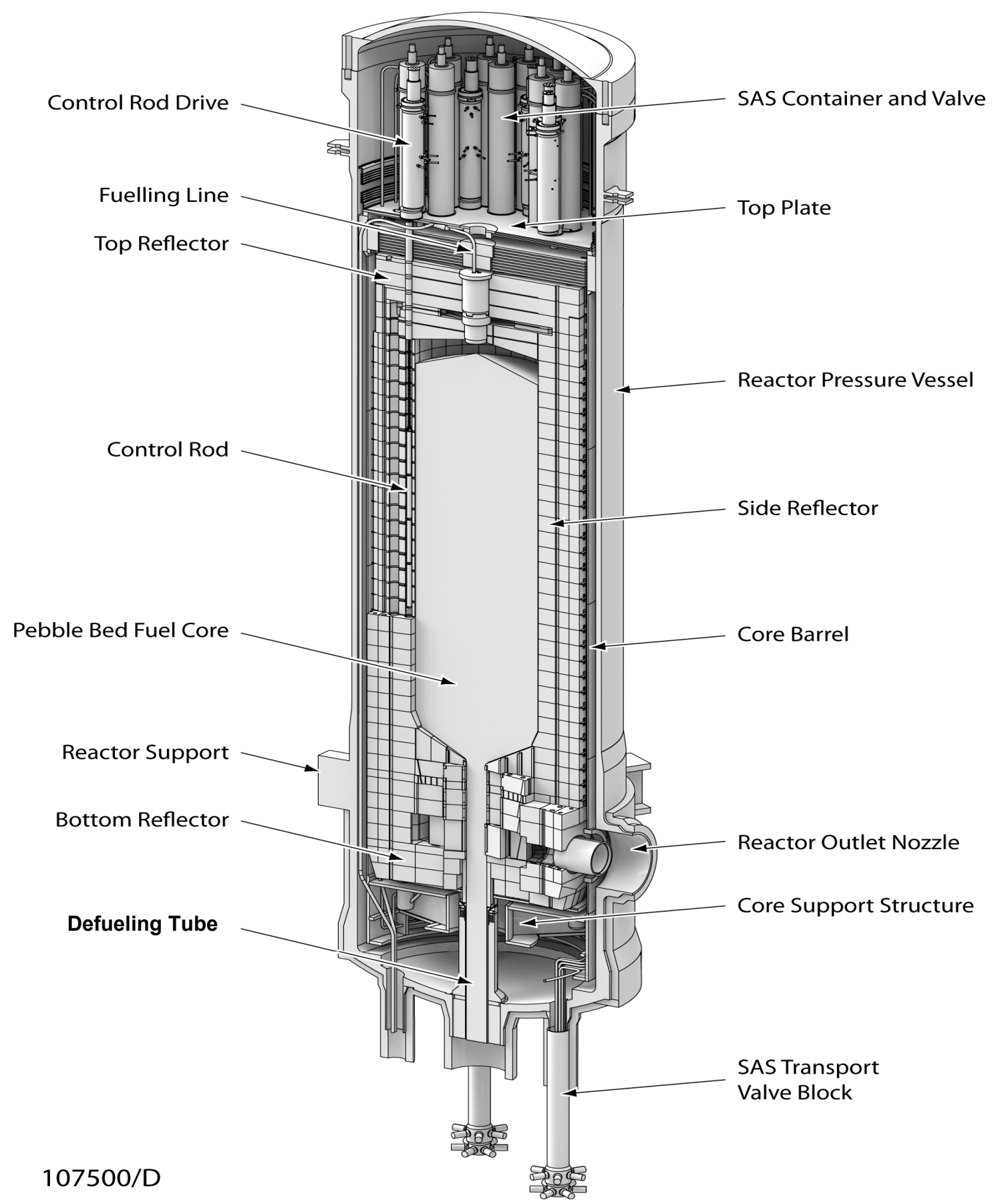

Figure 1. Schematic of the AREVA HTR-Module pebble-bed reactor unit. 


\subsubsection{Fuel Spheres (Pebbles)}

The pebble-bed core consists of hundreds of thousands of individual spherical fuel elements (pebbles), each containing fuel particles distributed throughout a graphite matrix. As shown in Figure 2, the fuel sphere comprises numerous TRISO-coated fuel particles embedded in a graphite matrix, surrounded by a 5-mm-thick fuel-free graphite shell. In the AREVA HTR-Module reactor, each sphere will contain $7 \mathrm{~g}$ of $\mathrm{UO}_{2}$ with a $\mathrm{U}-235$ enrichment ranging from about 4.2 to $4.5 \%$ (startup fuel) to $7.8 \%$ (fuel for the equilibrium cycle). The fuel spheres will pass through the core 15 times before reaching discharge burnup.

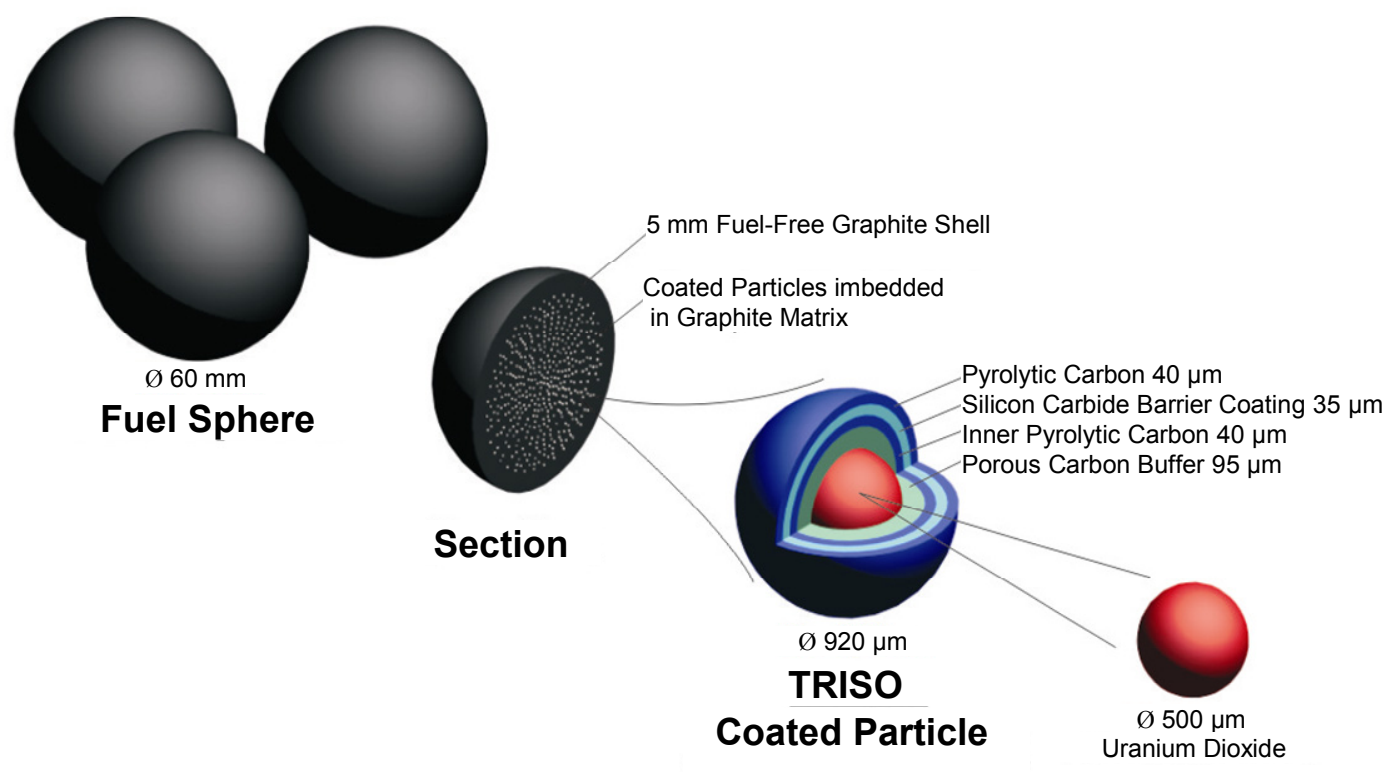

Fuel Kernel

Figure 2. Design of a fuel sphere. ${ }^{19}$

The Westinghouse PBMR fuel spheres are of the same construction as shown in Figure 2; however, they are planned to each contain $9 \mathrm{~g}$ of $\mathrm{UO}_{2}{ }^{18}$ and will pass through the core only six times before they reach target discharge burnup.

\subsubsection{Pebble Fuel Handling and Storage}

The fresh pebble fuel spheres arrive in sealed canisters within shipping containers and are placed into fresh-fuel storage after receiving inspection. Figure 3 illustrates the fuel-handling system for the AREVA HTR-Module, while Figure 4 illustrates the fuel-handling system for the Westinghouse PBMR. Both systems are conceptually very similar, up until the point that a fuel sphere is discharged, either due to damage or due to achieving target discharge burnup. In the PBMR design shown in Figure 4, the undamaged spent fuel is routed into passively cooled spent-fuel tanks. 


\section{FUEL HANDLING AND STORAGE \\ SYSTEM}

Process Flow - Normal Operation

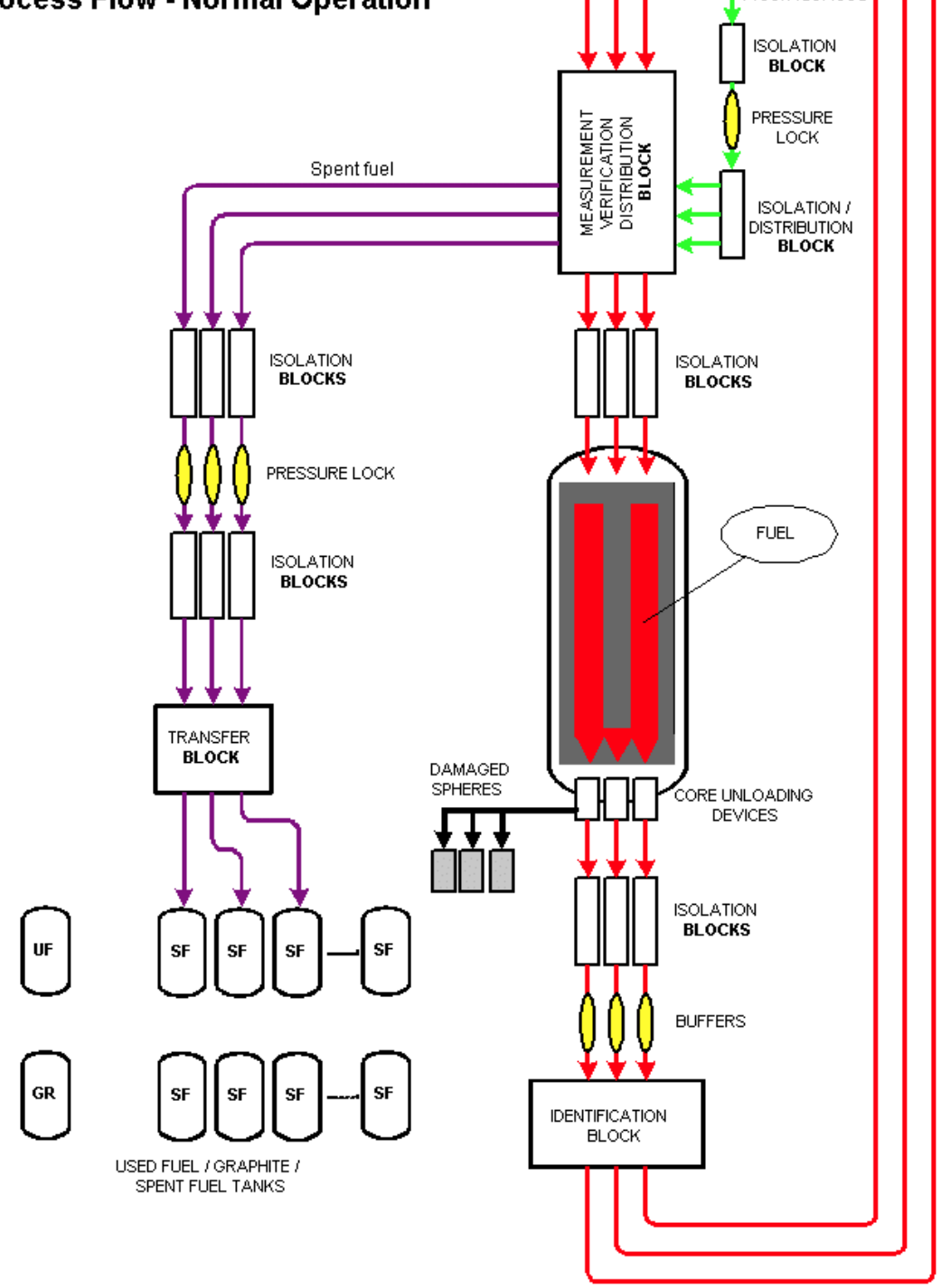

Figure 3. PBMR fuel-handling and storage system overview (normal operation). ${ }^{18}$ 


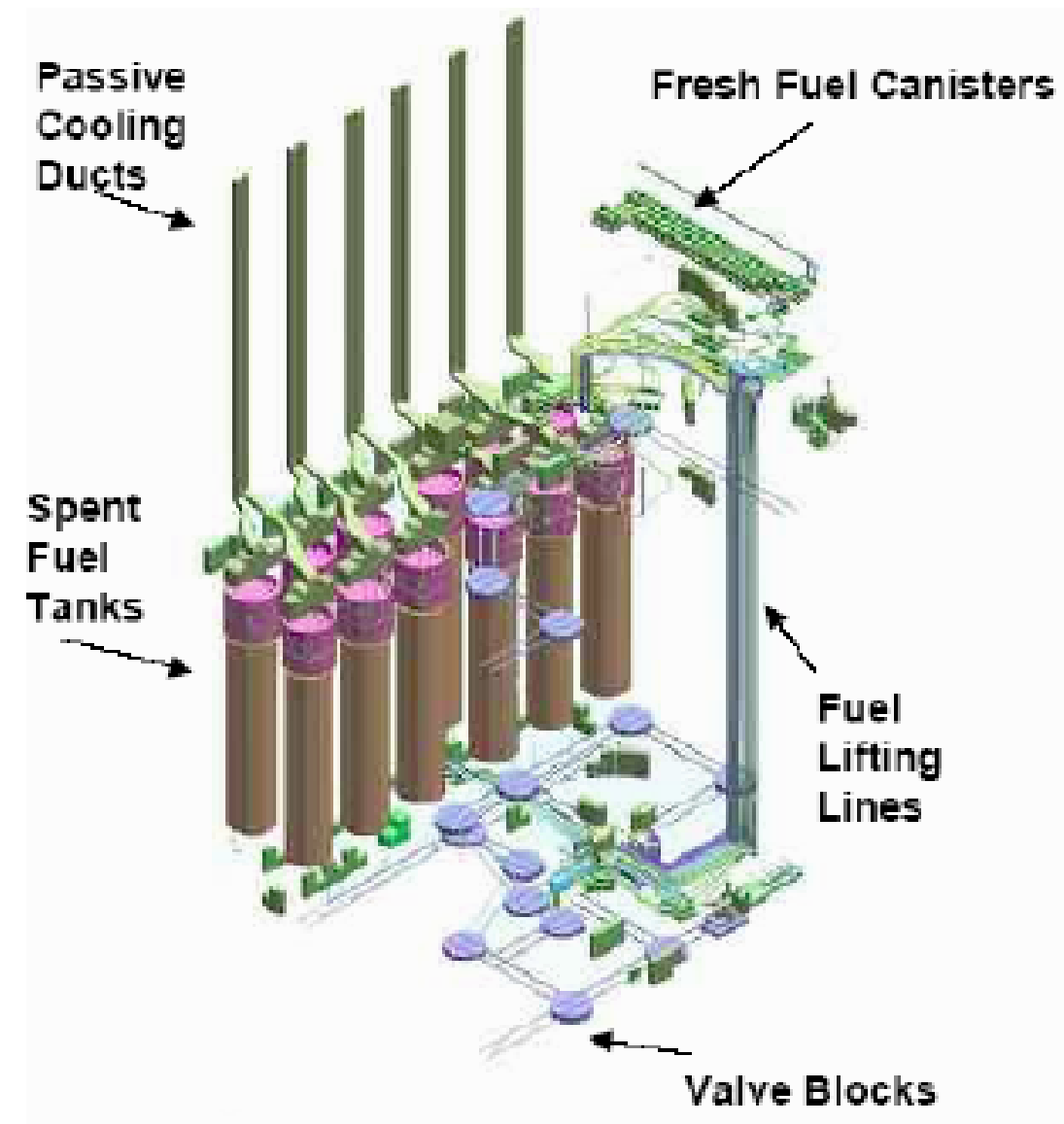

Figure 4. Westinghouse PBMR fuel-handling and storage system. ${ }^{20}$

\subsection{Prismatic HTGR, Fuel, Fuel Handling and Storage}

This section addresses MC\&A relevant design characteristics of the prismatic-fueled HTGRs (Section 2.2.1), their fuel designs (Section 2.2.2), and their fuel-handling and storage systems (Section 2.2.3).

\subsubsection{Prismatic Fueled HTGR}

The prismatic HTGR concept is a high-temperature, gas-cooled, graphite-moderated reactor utilizing a prismatic graphite-block fuel form. The core configuration is fixed during operation, and like a conventional light water reactor (LWR), refueling is performed periodically during reactor shutdown. This is in direct contrast to the pebble-fueled concepts that use on-line refueling.

The NGNP candidate prismatic reactor designs will be based on the 350-MWth modular high-temperature gas-cooled reactor (MHTGR) design and the 600-MWth GT-MHR design. Figure 5 illustrates the core configuration of the General Atomics GT-MHR. The prismatic fuel blocks are stacked 10 deep in 102 fuel columns in an annular configuration, surrounded by reflector blocks in the center, sides, and at the top and bottom. 


\section{Material Graphite 102 Fuel Columns Hexagonal Fuel Block Dimensions: \\ - Width Across Flats $0.36 \mathrm{~m}$ \\ - Height $0.8 \mathrm{~m}$ \\ Number of Fuel Blocks: \\ - Standard 720 \\ - Control 120 \\ - Reserve Shutdown 180 \\ Number of Fuel Compacts 2919600 Mass 870 Tons}

$22 \mathrm{ft}-5$ in.

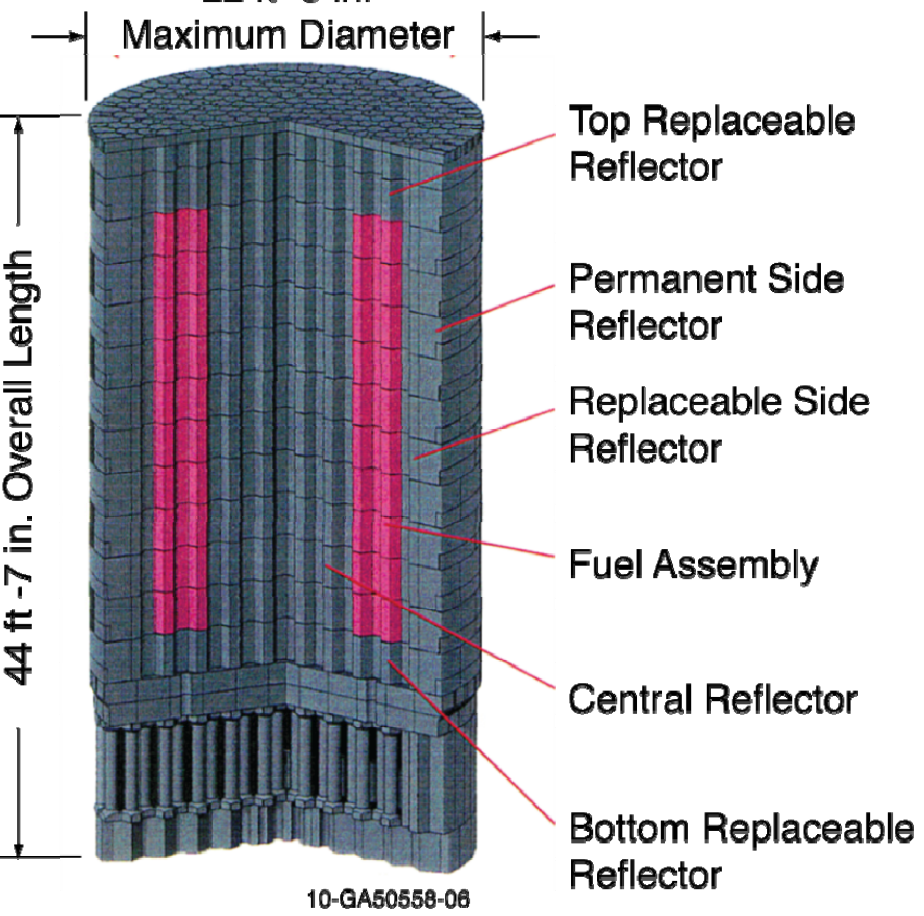

Figure 5. The General Atomics GT-MHR core design. ${ }^{19}$

\subsubsection{Prismatic Fuel}

The construction of a prismatic fuel block is illustrated in Figure 6. The fuel particles are bonded together in a carbonaceous matrix to form cylindrical compacts that are approximately $12.5 \mathrm{~mm}$ in diameter and up to about $50 \mathrm{~mm}$ long. These compacts are loaded into fuel channels bored into hexagonal-shaped graphite blocks, which are then sealed via the insertion of a graphite plug that is glued into the top each fuel channel. Each prismatic fuel element is marked with a unique serial number that facilitates item-based accountancy.

The steam cycle modular helium reactor (SC-MHR) that General Atomics describes in its NGNP Conceptual Design Project Report ${ }^{21}$ is a recent variant of the GT-MHR that contains a total of 660 fuel elements. The fuel particles have a nominal enrichment of 15.5 weight percent U-235. 


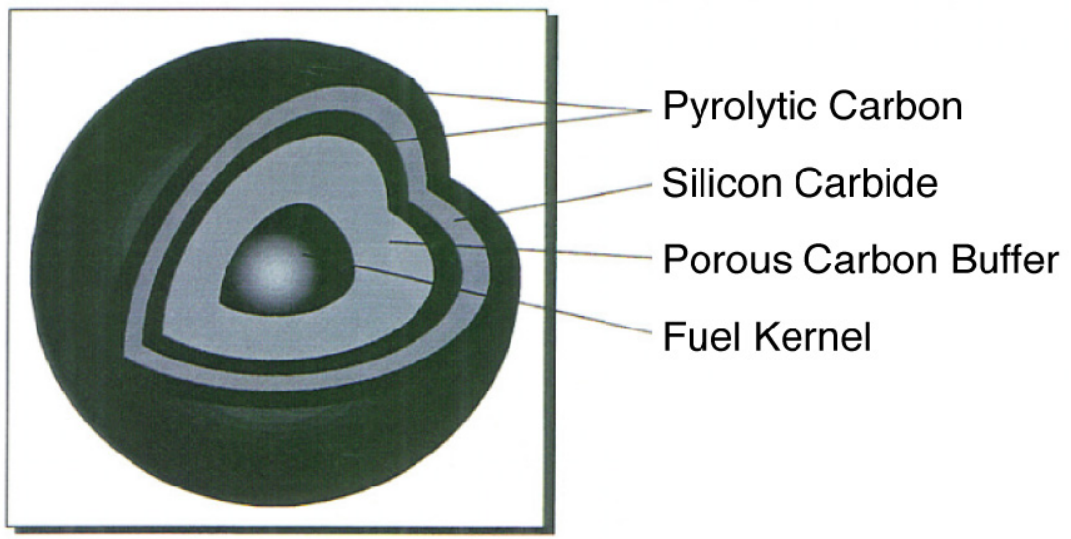

Fuel Particle

\section{Fuel Compact}

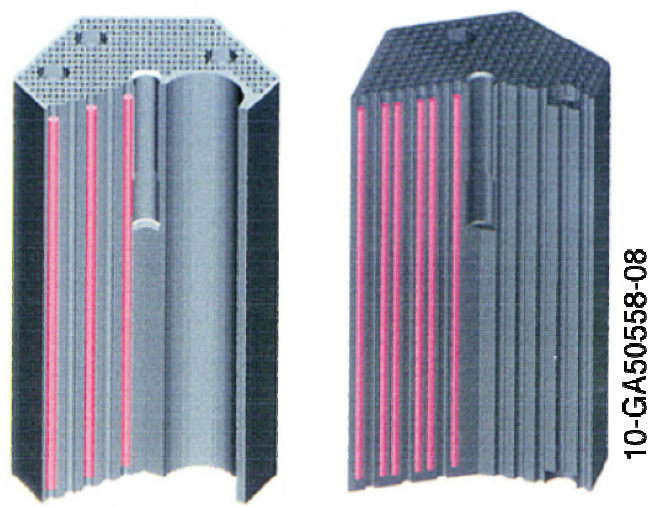

\section{Fuel Assemblies}

Figure 6. Prismatic fuel-element concept. ${ }^{21}$ 


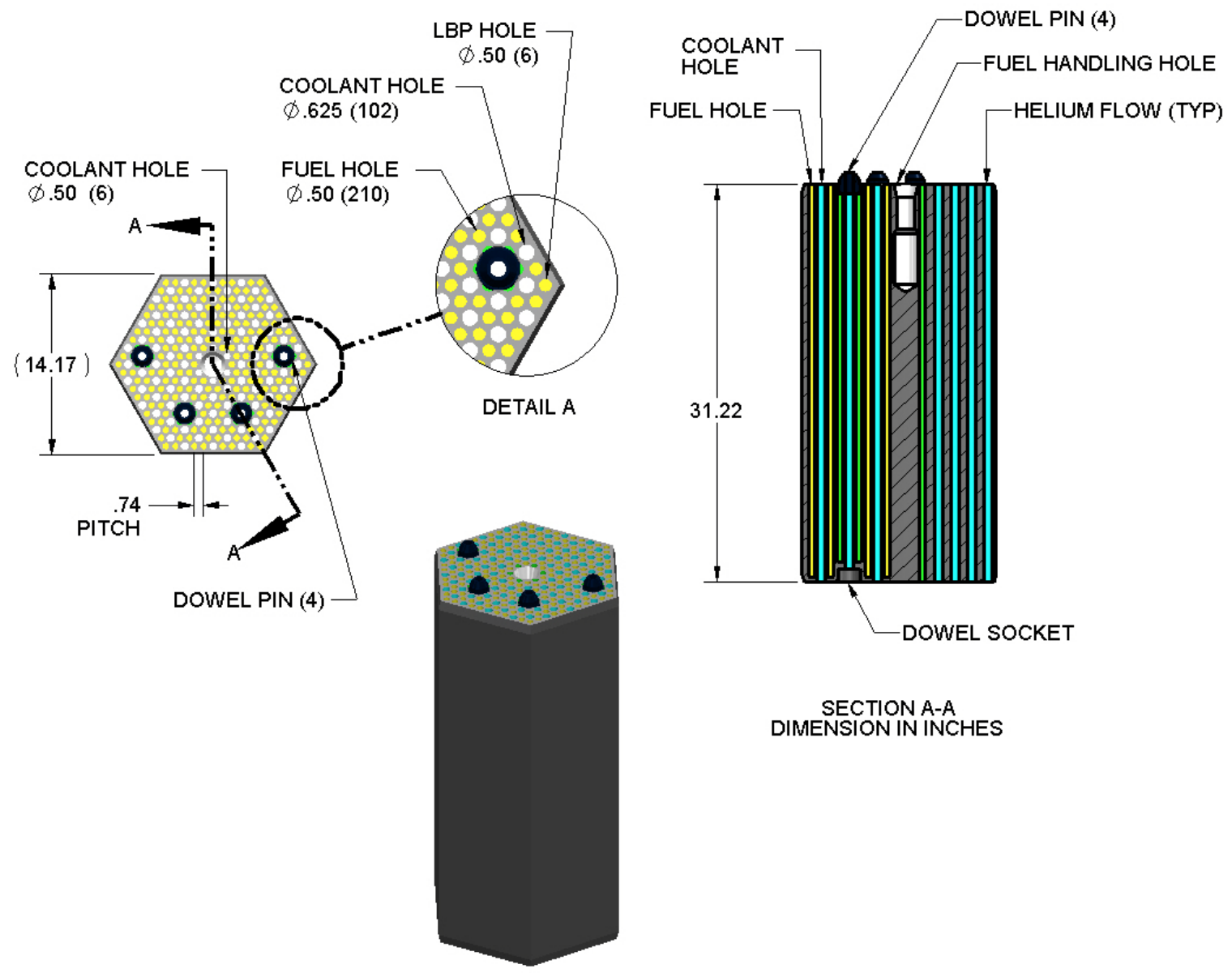

Figure 7. SC-HTR standard prismatic fuel element. ${ }^{21}$

\subsubsection{Fuel Handling and Storage}

While details may vary from plant to plant, the prismatic-fueled plants will have the following elements for fuel handling and storage. In the GT-MHR, the principal locations of interest are:

- Entry location for fuel receipt and shipment.

- Fuel sealing and inspection facility:

- For transferring new fuel to the new fuel-storage facility

- For packaging cooled spent fuel for later on-site dry storage or offsite disposal.

- New fuel-storage facility.

- Fuel storage pools (spent fuel is initially stored dry in fuel storage wells, which are immersed in water filled pools. In the GT-MHR, there are 350 fuel storage wells, and the fuel elements are stacked 8 layers deep).

- On-site dry spent fuel storage. 


\section{ANALYSIS AND INTERPRETATION OF RELEVANT NRC REGULATIONS AND GUIDANCE FOR MC\&A}

\subsection{Background}

The MC\&A regulations applicable to nuclear power reactors were originally promulgated by the Atomic Energy Commission (AEC) in the February 3, 1956, issue of the Federal Register. ${ }^{22}$ These were part of a generally applicable requirement that all licensees possessing special nuclear material (SNM) "keep records showing [its] receipt, inventory, and transfer". ${ }^{22}$ By the early 1960s, power-reactor licensees were required to submit reports of SNM transactions with other facilities and material status reports documenting their SNM inventory and additions to and removals from inventory. During this period, the AEC safeguards approach relied upon the intrinsic value of SNM billing licenses for the value of SNM leased from the AEC that could not be accounted for. When private ownership of SNM was legalized in August 1964, the AEC believed that the high cost of SNM, in combination with the severe criminal penalties in the Atomic Energy Act, would provide licensees with adequate incentives to prevent diversion. In the mid 1960s, incidents occurred that called this regulatory approach into question, and the AEC began strengthening the MC\&A requirements. ${ }^{23}$ In 1967, the AEC added a requirement that power reactors conduct an annual physical inventory to verify that the material on the inventory of record (book inventory) was physically present. These requirements were documented in 10 CFR $\S 70.51$. In 1987, the NRC added the requirement for power reactors to report incidents that indicated theft or diversion of SNM. In 2002, all MC\&A requirements were moved to Part 74 of 10 CFR. The three basic MC\&A requirements that apply to power reactors were moved from 10 CFR 70.51 Sections (b), (c), and (d) to 10 CFR 74.19 Sections (a), (b), and (c). In addition, nuclear power reactors are subject to reporting requirements in 10 CFR $\S 74.11$ (reports of indications of theft or diversion of SNM), 10 CFR $\S 74.13$ (material status reports), and $10 \mathrm{CFR} \S 74.15$ (material transaction reports). ${ }^{22}$

The NRC regulations and their implementation by nuclear power reactors received additional scrutiny because of a June 2000 event in conjunction with the decommissioning of Unit 1 of the Millstone Nuclear Power Plant. In 1972, a spent fuel assembly had been disassembled for off-site inspection to determine the effect on the fuel rods from a failure of the condenser tubes that permitted seawater to enter the reactor coolant. In 1974, when the fuel rods were returned from the off-site inspection and the fuel assembly was reassembled, a tie-rod that had been damaged in handling and a center spacer capture rod were not included in the assembly. These two rods were thought to be stored in a separate 8-rod container. However, accountability for these two rods was lost, and they could not be found during the 2000 physical inventory. This prompted the licensee to report the loss to the NRC. ${ }^{24}$

NRC instructed its resident inspectors to review MC\&A and other records to determine whether reactor facilities had ever reconstituted fuel or removed rods from an assembly. At those reactors where this occurred, the NRC resident inspectors reviewed the MC\&A programs to assess their effectiveness. On April 20, 2004, in response to concerns from the resident inspectors regarding the effectiveness of the spent fuel pool inventory methods at Vermont Yankee, the licensee found that two spent fuel rod pieces were not in their documented locations in the spent-fuel pool. The licensee assembled an investigation team in an attempt to locate the two missing fuel rods, and the NRC initiated a special inspection. On July 13, 2004, after an extensive search, the pieces were located in the spent fuel pool. In July 2004, the licensee for Humboldt Bay (a decommissioned reactor) notified the NRC of a discrepancy between inventory records and the location of three fuel-rod segments. Subsequent investigation at Humboldt Bay identified that one in-core detector and parts of three other in-core detectors containing SNM were also missing. ${ }^{22}$ 
On February 11, 2005, the NRC issued Bulletin 2005-01, "Material Control and Accounting at Reactors and Wet Spent Fuel Storage Facilities." This bulletin notified licensees about concerns with control and accounting of SNM at power reactors and wet spent fuel storage facilities and requested that licensees:

- Provide a description of their physical inventory and accounting processes to the NRC within 30 days of the date of the bulletin

- Confirm the accuracy of their accounting records, visually confirm all SNM items in their spent-fuel pools, and report the results to the NRC within 90 days.

In its response to this bulletin, Oconee Nuclear Power reported that it could not account for a spent-fuel item, which was subsequently found. The NRC conducted special MC\&A inspections at all power reactors and wet spent fuel storage sites. Numerous violations of NRC regulations were identified, but there were no additional cases where SNM could not be accounted for. ${ }^{22}$

During this period, there were also two publicly available independent reviews that addressed MC\&A at power reactors: an NRC Inspector General Assessment, ${ }^{25}$ and a Government Accountability Office assessment of the performance of nuclear power plants in controlling and accounting for spent fuel. ${ }^{26}$

Based on analysis of the findings of the NRC inspections and the independent reviews, the NRC staff determined that there was no need to revise the NRC regulations. Instead, their approach was to revise the regulatory guides for MC\&A at power reactors (Regulatory Guide 5.29, "Nuclear Material Control Systems for Nuclear Power Plants" and Regulatory Guide 5.49, "Internal Transfers of Special Nuclear Material") to clarify that the regulations apply to separated rods and pieces. ${ }^{22}$ As of June 2010, NRC had not issued proposed revisions to either guide. . $, 27,28,29^{2}$

\subsection{Nuclear Power Plant MC\&A Requirements}

The current requirements for MC\&A at nuclear power plants are contained in 10 CFR 74 Sections 74.11, 74.13, 74.15, and 74.19. ${ }^{30}$ These requirements are listed in Appendix A. Section 74.11 requires nuclear power plant licensees to notify the NRC of loss, theft, or attempted theft of SNM. Sections 74.13 and 74.15 require nuclear power plant licensees to report SNM balances and transactions, respectively, to the NRC. Section 74.19 contains the requirements for the MC\&A program at nuclear power plants. These requirements can be summarized as:

- Establish, maintain, and follow written procedures sufficient to account for all SNM possessed under license

- Keep records concerning receipt, inventory (including location and unique identity), acquisition, transfer, and disposal of all SNM possessed

- Perform physical inventories of all SNM possessed at least every 12 months.

Unlike most types of facilities subject to 10 CFR 74 requirements, nuclear power plants are not to obtain documented NRC approval required for their MC\&A program through submittal of a Fundamental Nuclear Material Control Plan. (See, for example, 10 CFR 74 Sections 74.31(b), 74.33(b)(1), 74.41(b)(1), and 74.51(c).) Rather, the NRC may inspect the nuclear power plant's MC\&A procedures and records to determine whether these requirements are being met. Guidance for an acceptable nuclear power plant

a. The update of Regulatory Guide 5.29 is complicated because the guide was withdrawn on January 15, 1988, because "equivalent recommendations have been incorporated in approved codes or standards". ${ }^{27}$ The withdrawn guide contained no guidance beyond an endorsement of ANSI NI5.8-1974, "Nuclear Material Control Systems for Nuclear Power Plants.",28 The ANSI N15.8 standard was reissued in $2009 .{ }^{29}$ Because an update of Regulatory Guide 5.29 would presumably contain no guidance beyond an endorsement of ANSI N15.8-2009, a revised regulatory guide may not be issued. 
MC\&A program is found in ANSI N15.8-2009, ${ }^{29}$ which replaced Regulatory Guide 5.29, Nuclear Material Control Systems for Nuclear Power Plants. This standard supplements the requirements of 10 CFR 74 with the following guidance:

\subsubsection{General Program Guidance}

- Material control functional and organizational relationships shall be set forth in writing in organizational directives, instructions, procedures, manuals, or other documents. Documentation should include position qualification requirements and definitions of authority, responsibilities, and duties. The assignment of SNM control and accounting functions should be such that the activities of one person or unit serve as a control over and a check of the activities of other persons or units.

Activities involving handling, accounting, or control of SNM should be verified by a second person. Specific assignments of responsibilities should be prescribed for all facets of the SNM control system. Delegation of material control responsibilities and authority should be in writing. Material control functions should be assigned as follows ${ }^{\mathrm{b}}$ :

- The plant manager at each nuclear power plant should have overall physical control and physical inventory responsibilities for SNM at the plant site

- The SNM manager should have overall responsibility for implementation of the SNM control and accounting function

- The SNM custodian at each nuclear power plant should be responsible for the performance of the functions that relate to the control of SNM.

- Personnel responsible for SNM control and accounting should have experience or training applicable to their functions.

- The utility should establish an SNM accounting group. This group should maintain records for the SNM in the plant's possession (as required by 10 CFR $74.19[\mathrm{~b}]$ ).

- Each utility shall prepare and maintain written procedures covering the SNM control and accounting system for each nuclear power plant, as required by 10 CFR 74.19(b). These procedures shall address, as a minimum, the following topics:

- Organization and personnel responsibilities and authorities

- Designation and description of item control areas (ICAs)

- Material control records and reporting

- Notification for events concerning SNM

- Receiving and shipping SNM

- Internal transfer of SNM

- Physical inventory of SNM

- SNM element and isotopic calculation method

- Characterization and identification of items as SNM or non-SNM to preclude loss of control of SNM items.

- Provisions shall be made for written approval of revisions to the contents of the SNM control and accounting procedures by the appropriate utility personnel, such as the SNM manager.

- Discrepancies or program deficiencies shall be documented, investigated, reported - as required by 10 CFR 74.11 and 10 CFR 20.2201—and resolved using the utility corrective action program.

b. Titles assigned to the positions are descriptive only. Organizations, specific titles, and related functions may vary. 
- The utility should establish a program to ensure adequate oversight of vendors/contractors conducting activities involving handling, accounting, and control of SNM.

\subsubsection{Receipt of Fresh Fuel}

- The utility or its representative should review the adequacy of the fuel supplier's MC\&A system used in establishing the quantities and assays of SNM. In the event of a significant discrepancy between the fuel supplier's values for SNM quantities and assays and those determined by the utility, the cause of such discrepancies should be investigated with the fuel supplier and the differences should be resolved and reconciled expeditiously.

- For SNM received at the utility, the utility:

- Shall contact the shipping vendor in the event the SNM does not arrive as scheduled; initiate an investigation and resolve, as required by 10 CFR 73.67 and 10 CFR 74.11

- Shall verify the integrity of the shipping container and tamper-safing devices and resolve any problems identified, as required by 10 CFR 73.67 and 10 CFR 74.11

- Shall verify that the quantity (item count) and unique identification numbers agree with those indicated on the shipper's documents

- Shall take appropriate steps to resolve and reconcile any differences in quantities or identification numbers, as required by 10 CFR 73.67 and 10 CFR 74.11

- $\quad$ Shall notify the regulatory body, as required by 10 CFR 73.67 and 10 CFR 74.11.

- The SNM custodian should report the receipt of each item containing SNM, by serial number or other unique identifier, to the accounting group. The receipt of SNM shall be documented in the material control records and the book inventory updated for the applicable ICA, as required by 10 CFR 74.19(a). A nuclear material transaction report (DOE/NRC Form 741) shall be completed, as required by 10 CFR 74.15 .

\subsubsection{Shipments}

- Procedures for shipment shall be established, as required by 10 CFR 74.19(b), to provide for:

- Verification and recording of the serial number or unique identifier of each item containing SNM

- Recording of the quantities of SNM contained in each item

- Reporting the quantity of SNM shipped, if the quantity is reportable, as required by 10 CFR 74.15

- Verification of compliance with regulations, including licensing, transportation, and security requirements for shipment

- $\quad$ Reporting the completion of each shipment to the accounting group.

Care should be taken to assure that SNM contained in fuel is not shipped inadvertently with shipments of non-fuel SNM waste.

- The shipment of fuel assemblies, fuel components, or non-fuel SNM shall be documented in the material control records and the book inventory updated for the applicable ICA. A nuclear material transaction report (DOE/NRC Form 741) shall be completed, as required by 10 CFR 74.15.

- For SNM being reprocessed, the utility or its representative shall:

- Review the adequacy of the reprocessor's material control system used in establishing the quantities and assays of SNM, including written procedures

- Audit the implementation of the reprocessor's material control system used in establishing the quantities and assays of SNM, including observation of measurement and material control activities 
- Audit the reprocessor's accounting activities, measurements, analyses, computations, and records affecting the determination of SNM quantities and assays

- In the event of a significant discrepancy between the reprocessor's values for SNM quantities and assays and those determined by audit, investigate and reconcile any differences expeditiously.

\subsubsection{Item Controls}

- The nuclear power plant shall control fuel assemblies, fuel-component containers, non-fuel SNM containers, sealed containers, reassembled reactor vessels, dry storage canisters, or discrete pieces of SNM (fuel or non-fuel) that is not stored in a container, as items as appropriate.

- A container with a tamper-safing device can be treated as a single item for control and inventory purposes; however, before the container is closed and the tamper-safing device is installed, the contents shall be physically inventoried. If the contents of a sealed container are accessed, the contents shall be physically re-inventoried or administrative procedures shall be in place to ensure the integrity of the contents before it can be treated as a single item for inventory purposes.

- $\quad$ Non-SNM items stored with items containing SNM shall be clearly identified as such to preclude SNM items from being mistaken for non-SNM items.

- ICAs should be established for physical and administrative control of SNM. Each ICA should be an identifiable physical area such that each unit of SNM being moved into or out of the ICA can be counted, identified, and documented. The number of ICAs should be sufficient to establish control of the SNM.

- Transfers of SNM into, out of, or within an ICA should be accomplished only upon written authorization of the SNM custodian or other individual(s) at the plant site responsible for the SNM program. Written authorization should be obtained prior to the movement. Transfers should be controlled (and documented) by item serial number or unique identifier and by ICA location. All transfers of SNM should be documented using a material control record by the responsible person involved in each operation, and the book inventory should be updated for the applicable ICA.

\subsubsection{Physical Inventory}

- Physical inventory shall be taken at intervals not to exceed 12 months, as required by 10 CFR 74.19(c). Physical inventory shall be conducted according to written inventory procedures, as required by 10 CFR 74.19(b).

- Physical inventory shall include all SNM possessed under license and shall be conducted in all ICAs, including:

- New fuel storage areas

- Irradiated fuel storage areas

- Reactors

- Independent spent fuel storage installations

- Areas containing non-fuel SNM.

- The inventory shall include an item count of all SNM in item form, as required by 10 CFR 74.19(c).

- For fuel assemblies and fuel-component containers, an item count is sufficient. If the contents of an assembly or a fuel-component container are accessed, the contents shall be physically re-inventoried before the assembly or container can be treated as a single item for inventory purposes.

- For fuel components that are not part of an intact assembly, physically captured in an assembly, stored in a sealed container, or stored in a fuel-component container, each component shall be inventoried. 
- Severe damage to cladding, where rod structural integrity has not been maintained, can result in inadvertent physical separation and dispersal of fuel components from the fuel rod. Upon visual identification of inadvertent physical separation, an estimate of the SNM quantity and an engineering judgment concerning the origin of the SNM should be made and documented. The amount of irretrievable or inadvertent loss should be reported, if the quantity is reportable, as required by 10 CFR 74.13. Methods used to estimate SNM quantities include, for example, engineering calculation, engineering judgment, physical measurement of length, destructive or non-destructive measurement, and count of the number of pellets retrieved or missing. These fuel components should be stored in a fuel-component container if practicable.

- For sealed containers, verification of the integrity of the tamper-safing device is sufficient.

- Whenever fuel assemblies are loaded into a reactor, the unique identifier and location of each item shall be visually verified. When the reactor vessel is reassembled, the reactor is considered one item for inventory purposes.

- For non-fuel SNM, the method of physical inventory depends on the method of storage and use:

- For installed components, verification shall be performed at the time of installation, and administrative procedures and controls shall be established so that records concerning the location and unique identity are accurate.

- For non-installed components stored in primary containment, administrative procedures and controls shall be established so that records concerning the location and unique identity are accurate when the reactor is at power, and verification shall be performed during refueling outages.

- For non-fuel SNM containers, item count of the containers is sufficient. If the contents of the container are accessed, the contents shall be physically re-inventoried or administrative procedures shall be in place to ensure the integrity of the contents before the container can be treated as a single item for inventory purposes.

- The physical inventory shall be reconciled to the book inventory. Discrepancies between the physical inventory and the book inventory shall be investigated and resolved expeditiously. After reconciliation of discrepancies, the book inventory shall be adjusted to agree with the result of the physical inventory.

- The results of the physical inventory of SNM shall be documented in the material control records of the applicable ICA and utilized as input to the isotopic calculations. A material balance report (DOE/NRC Form 742) and physical inventory listing (DOE/NRC Form 742C) shall be completed, as required by 10 CFR 74.13 .

\subsubsection{Fuel Burn-up Calculations}

- Methods of computation shall be established and utilized for determining the total element and isotopic composition of SNM in irradiated nuclear fuel assemblies and fuel components. The computed values are the basis for shipment documents, as required by 10 CFR 74.15, and material status reports, as required by 10 CFR 74.13 .

- Refinement of the element and isotopic computations used in determining the SNM content of irradiated fuel should be considered as new technologies evolve. For reprocessed fuel, this may include a collection and comparison of reprocessing plant measurement data with computed data for fuel assemblies. 


\subsubsection{Records and Reports}

- Records shall be created and retained, as required by 10 CFR 74.19(a). The accounting records are the basis for the MC\&A program. Quantitative data generated by the utility's calculations of changes in quantities and isotopic composition due to irradiation and decay shall be recorded and reported in accordance with the utility's standard recording and reporting procedures. The records and reports system shall include:

- An accounting system for maintaining the book inventory

- Material control records maintained for each ICA

- Reconciliation of the results of physical inventories to the book inventory

- Recording the transfer of SNM into or out of each ICA

- Recording movement of SNM between locations within an ICA, for ICAs where locations (e.g., spent fuel racks) have been established

- Recording the creation of items containing SNM, such as creation of a rod fragment

- Recording the estimated quantity and origin of SNM that has been inadvertently separated from fuel upon the discovery of the separation

- Reporting to the accounting group the transfer of SNM into, within, or out of an ICA, if applicable

- Perpetual inventory records of each ICA, including the serial number or other unique identifier and location of each item in the ICA that contains SNM

- Historical data of SNM in each nuclear fuel assembly, fuel component, or non-fuel SNM item while in the possession of the utility

- Retention as required by 10 CFR 72 and 74, as applicable.

\subsubsection{Program Reviews}

- Review of the MC\&A program should be conducted periodically. The results of the review should be documented and reported in accordance with the requirements of the utility's quality assurance or self-assessment program.

\subsection{Adaptation to Reactors Other than Light Water Reactors}

The current nuclear power plant MC\&A requirements and guidance are applicable to the LWRs where almost all SNM is in item form. It may be appropriate for alternative nuclear power plant designs, such as the HTGR prismatic and pebble-bed reactor designs. It is impossible to predict with certainty how the NRC will adapt the regulations and guidance to such designs. However, based upon the historical reluctance of the NRC to revise its requirements in this area, as discussed in Section 3.1, the general reluctance of the NRC to develop design-specific requirements, and the performance-based nature of the current requirements, it is very likely that the NRC will leave the regulations unchanged and develop design-specific guidance. The NRC took this approach for the Fort St. Vrain (FSV) HTGR, which was a prismatic design. Because the prismatic fuel assemblies can be considered items, it is likely that few, if any, changes to the current guidance will be required for the prismatic-fueled HTGR design. A discussion of MC\&A for the prismatic-fueled HTGR is presented in the next section.

For the pebble-bed HTGR design, it is likely that significant changes to the portions of the current guidance regarding physical inventory will be required. There are developmental approaches that might make it possible to uniquely identify each pebble as an item. ${ }^{31}$ However, the large number of pebbles, approximately 400,000 (see Section 2.1.1.1), would render item accounting impractical even if these developmental approaches could be implemented. In addition, because the pebble-bed HTGR design 
accommodates online refueling, there is no closed reactor vessel that can be considered as a single item. However, the individual pebbles contain relatively small amounts of SNM $\left(\sim 7\right.$ grams of $\mathrm{UO}_{2}$ at enrichments ranging from 4.2 to $7.8 \%$ uranium-235). Therefore, it is likely that the NRC inventory guidance for the pebble-bed reactor will be based on a statistical verification of the number of spheres and their approximate SNM content. Based on the MC\&A requirements for comparable facilities, the statistical verification method will probably need to have a $95 \%$ probability of detecting the loss or alteration of 18,700 pebbles. ${ }^{c, 32}$ A discussion of MC\&A for the pebble-bed HTGR design is provided in Section 5 .

c. For low-enriched uranium facilities, NRC requires a measurement control program that maintains twice the standard error on inventory difference at 9,000 grams of U-235. ${ }^{32}$ A loss of twice the standard deviation will be detected as significantly different from zero loss, with an approximately $95 \%$ probability in a standard inventory difference limit of error on inventory difference test. A loss of 9,000 grams of U-235 corresponds to about 18,700 pebbles at the higher (7.8\%) enrichment. 


\section{MC\&A FOR THE PRISMATIC-FUELED HTGR}

\subsection{Introduction}

This section provides a brief description of an MC\&A program suitable for the prismatic-fueled HTGR likely to meet the NRC requirements and guidance for MC\&A programs discussed in Section 3. The authors recommend early and frequent interaction with NRC during the design process in order to provide assurance that their MC\&A approach will be acceptable to NRC. The following discussion focuses on those aspects of the MC\&A program where the nuclear power plant design can enhance the effectiveness or reduce the operational impact of the MC\&A program.

The MC\&A program for the prismatic HTGR is expected to be very similar to the current MC\&A program for LWRs as discussed in Section 3. The essential elements of that MC\&A program are discussed below.

\subsection{Essential Elements of Prismatic-Fueled HTGR MC\&A Program}

\subsubsection{MC\&A Organization}

Material control functional and organizational relationships are documented in plant directives, instructions, procedures, manuals, or other documents. Documentation includes position qualification requirements and definitions of authority, responsibilities, and duties. The assignment of SNM control and accounting functions is such that the activities of one person or unit serve as an over check and control over the activities of other persons or units. Policies or procedures require that activities involving handling, accounting, or control of SNM by one individual are independently verified by a second person. Responsibilities are assigned in writing for all facets of the SNM control system. Delegation of material control responsibilities and authority are made in writing. Material control functions should be assigned in accordance with 4.2.1.1 through 4.2.1.4. The specific titles are only descriptive-organizations, specific titles, and related job functions may vary. However, the level of organizational authority and control would be expected to be similar to that specified.

\subsubsection{Plant Manager}

The plant manager has overall responsibility for physical control and physical inventory responsibilities for SNM at the plant site.

\subsubsection{SNM/Nuclear Materials Manager}

The SNM/Nuclear Materials manager has overall responsibility for implementation of the SNM control and accounting function. This individual may also have responsibility for nuclear fuel management.

\subsubsection{SNM Custodian}

The SNM custodian at the nuclear power plant is responsible for the performance of the functions that relate to the control of SNM. This individual supervises the ICA custodians. The SNM custodian is responsible for the planning and oversight of the annual physical inventory.

\subsubsection{ICA Custodians}

The ICA custodians are responsible for the items in their ICAs and acknowledge and control transfers of items in and out of their ICAs in writing or by electronic signature. 


\subsubsection{Accountability Group}

The SNM accountability group, which is typically at the plant site but may be centralized, maintains records for the SNM in the plant's possession (as required by [10 CFR 74.19(b)]). Members of this group may also perform the fuel burn-up calculations necessary to adjust the SNM inventory to account for fuel irradiation in reactor.

\subsubsection{Policies and Procedures}

The plant prepares and maintains written procedures addressing all aspects of the plant MC\&A program, as required by 10 CFR 74.19(b). These procedures address, as a minimum, the following topics:

1. Organization and personnel responsibilities and authorities

2. Training and qualification requirements for MC\&A personnel

3. Designation and description of ICAs

4. Material control records and reporting

5. Notification for events concerning SNM

6. Receiving and shipping SNM

7. Internal transfer of SNM

8. Physical inventory of SNM

9. SNM element and isotopic calculation method

10. Characterization and identification of items as SNM or non-SNM to preclude loss of control of SNM items

11. Program reviews and corrective actions.

The content and revisions of the MC\&A program and procedures are controlled in writing, by the appropriate plant personnel (e.g., the SNM manager), under the general plant procedures program or specific MC\&A program procedures.

\subsubsection{SNM Receipt and Shipment}

\subsubsection{Review of Fuel Supplier's Values}

The utility or its representative reviews the adequacy of the fuel supplier's MC\&A system used to establish the quantities and assays of SNM in the prismatic fuel elements. In the event of a significant discrepancy between the fuel supplier's values for SNM quantities and assays and those determined by the utility, the cause of such discrepancies are investigated with the fuel supplier, and the differences are required to be resolved and reconciled expeditiously.

\subsubsection{Receipt of Fuel/SNM}

For fuel or other SNM received at the plant, the plant:

1. Contacts the shipping vendor in the event the SNM does not arrive as scheduled; initiates an investigation and determines the reason that the shipment has not been received, as required by 10 CFR 73.67 and 10 CFR 74.11

2. Verifies the integrity of the shipping container and tamper-safing devices and resolves any problems identified, as required by 10 CFR 73.67 and 10 CFR 74.11 
3. Verifies that the quantity (item count) of prismatic fuel elements and their unique identification numbers (or the quantity and identification of other SNM) are in agreement with the information on the shipper's documents

4. Takes appropriate steps to resolve and reconcile any differences in quantities or identification numbers, as required by 10 CFR 73.67 and 10 CFR 74.11

5. Reports the receipt to NRC, as required by 10 CFR 73.67 and 10 CFR 74.11.

\subsubsection{Documentation of Receipt}

The SNM custodian reports the receipt of each item containing SNM, by serial number or other unique identifier, to the accounting group. The receipt of SNM is documented in the material control records and the book inventory updated for the receiving ICA, as required by 10 CFR 74.19(a). A nuclear material transaction report (DOE/NRC Form 741) is completed and submitted to NRC, as required by 10 CFR 74.15.

\subsubsection{SNM Shipments}

Procedures required by 10 CFR 74.19(b) provide for:

1. Verification and recording of the serial number or unique identifier of each item containing SNM

2. Recording of the quantities of SNM contained in each item

3. Reporting the quantity of SNM shipped, if the quantity is reportable, as required by 10 CFR 74.15

4. Verification of compliance with regulations, including licensing, transportation, and security requirements for shipment

5. Reporting the completion of each shipment to the accounting group.

These procedures address checks to ensure that SNM contained in fuel, especially from damaged prismatic fuel elements (See Section 4.2.5.10), is not shipped inadvertently with shipments of non-fuel SNM waste. Shipping procedures also require that the shipment of fuel assemblies, fuel components, or non-fuel SNM be documented in the material control records and the book inventory updated for the applicable ICA. A nuclear material transaction report (DOE/NRC Form 741) is required to be completed, as mandated by 10 CFR 74.15 .

\subsubsection{Review and Audit of Reprocessing (Recycling) Measurements}

For SNM in used prismatic fuel elements being reprocessed, the utility or its representative:

1. Reviews the adequacy of the reprocessor's material control system used in establishing the quantities and assays of SNM, including written procedures

1. Audits the implementation of the reprocessor's material control system used in establishing the quantities and assays of SNM, including observation of measurement and material control activities

2. Audits the reprocessor's accounting activities, measurements, analyses, computations, and records affecting the determination of SNM quantities and assays

3. In the event of a significant discrepancy between the reprocessor's values for SNM quantities and assays and those determined by audit, investigates and reconciles any differences expeditiously. 


\subsubsection{MC\&A Internal Controls}

The MC\&A program controls prismatic fuel assemblies, fuel-component containers, non-fuel SNM containers, sealed SNM containers, reassembled (i.e., closed) reactor vessels, dry storage SNM canisters, and discrete pieces of SNM (fuel or non-fuel) that are not stored in a container. Each of these units are identified in the material control records by a serial number or other unique identifier (e.g., a physical description of the item) and location, as required by 10 CFR 74.19(a).

\subsubsection{Item Control Areas}

The reactor plant is divided in ICAs for physical and administrative control of SNM. Each ICA is an area with defined physical boundaries so that each item being moved into or out of the ICA can be counted and identified. Each ICA is under the control of an ICA custodian who maintains records of the items contained within (book inventory, listing serial numbers/unique identifiers of items and their locations) and transferred into and out of his or her ICA. There are a sufficient number of ICAs to maintain control of the SNM. Typically, the new fuel storage area, spent fuel storage area, any spent fuel storage areas away from the plant (e.g., independent spent fuel storage installations) for which the plant has accountability responsibility, the reactor vessel, and laboratories and other areas housing non-fuel SNM are established as separate ICAs. Appendix A contains an example layout of ICAs that was developed for the application of international safeguards that may be considered for MC\&A purposes.

\subsubsection{Internal Transfers}

Transfers of SNM into, out of, or within ICAs are made only with written authorization of the SNM custodian or other individual(s) at the plant site responsible for the SNM program. Written authorization is obtained prior to the SNM movement. All transfers of SNM are documented in the MC\&A record system by the responsible persons involved in each operation, and the book inventories are updated for the applicable ICAs. For transfers between ICAs, the shipping ICA custodian and receiving ICA custodian acknowledge the transfers in writing or by electronic signature. Documentation of the transfer identifies the items transferred by their serial numbers or unique identifiers, the shipping ICA and location, the receiving ICA and location, and the authorization for the transfer.

\subsubsection{Physical Inventories}

Physical inventories are conducted at least annually, as required by 10 CFR 74.19(c) and are conducted according to written inventory procedures, as required by 10 CFR 74.19(b). Physical inventories are conducted in all ICAs and include an item count of all items including verification of the unique identifier and location of record.

\subsubsection{Prismatic Fuel Elements and Fuel-component containers}

For prismatic fuel elements and fuel-component containers, the inventory is taken by performing an item count with verification of unique identifier and storage location. All SNM items are included in the inventory.

Severe damage to prismatic fuel elements in which the integrity of the cylindrical compacts containing TRISO fuel particles has not been maintained can result in inadvertent physical separation and dispersal of the carbonaceous matrix containing the TRISO fuel particles. Upon visual identification of such damage, an estimate of the quantity of SNM separated from the fuel element is made. The amount of irretrievable or inadvertent loss is reported, if the quantity is determined to be reportable, as required by 10 CFR 74.13. Methods used to estimate SNM quantities include, for example, engineering calculations, engineering judgment, weighing the fuel element, and destructive or non-destructive measurement. Once 
the SNM quantity contained in the recoverable material that has been separated from the prismatic fuel element has been estimated, the recoverable material is secured in a fuel-component container and tamper-safed by two individuals who attest to the container contents. After the fuel-component container has been tamper-safed, it is considered an item for inventory purposes. If the contents of a fuel-component container are accessed, the contents are physically re-inventoried before the container can once again be treated as a single item for inventory purposes. For sealed containers, verification of the tamper-safing is performed as part of the physical inventory.

\subsubsection{Physical Inventory of Non-fuel SNM}

For non-fuel SNM, the method of physical inventory depends on the method of storage and use:

1. For installed components, verification is performed at the time of installation, and administrative procedures and controls are established so that records concerning the location and unique identity are accurate.

2. For non-installed components stored in primary containment, administrative procedures and controls are established so that records concerning the location and unique identity are accurate when the reactor is at power, and verification is performed during refueling outages.

3. For non-fuel SNM containers, the physical inventory is performed by item count of the containers. If the contents of the container are accessed, procedures require that the contents be physically reinventoried or administrative procedures be in place to ensure the integrity of the contents before the container can be treated as a single item for inventory purposes.

\subsubsection{Reconciliation of Physical and Book Inventories and Resolution of Discrepancies}

The physical inventory results are reconciled to the book inventory. Discrepancies between the physical inventory and the book inventory are required to be investigated and resolved expeditiously. Once discrepancies are resolved, the book inventory is adjusted to agree with the result of the physical inventory. Procedures require that the results of the physical inventory of SNM be documented in the material control records of the applicable ICA and employed as input to the isotopic calculations. The inventory results are documented on a Material Balance Report (DOE/NRC Form 742) and Physical Inventory Listing (DOE/NRC Form 742C), as required by 10 CFR 74.13.

\subsubsection{SNM Calculations}

\subsubsection{Element and Isotopic Computations}

Methods of computation are established and used for determining the total element and isotopic composition of SNM in irradiated prismatic fuel elements and fuel components. The computed values are the basis for shipment documents, as required by 10 CFR 74.15, and material status reports, as required by 10 CFR 74.13 .

\subsubsection{Refinement of Calculation Methods}

Procedures require that refining the element and isotopic computations used in determining the SNM content of irradiated fuel be considered as new technologies evolve. For reprocessed fuel, this may include a collection and comparison of reprocessing-plant measurement data with computed data for prismatic fuel elements. 


\subsubsection{System Review and Assessment}

Procedures require periodic - typically annual and no less frequently than triennial — review of the MC\&A program. The review is conducted and the results are documented and reported in accordance with the requirements of the utility's quality assurance or self-assessment program. Discrepancies or program deficiencies are documented, investigated, and reported, as required by 10 CFR 74.11 and 10 CFR 20.2201, and resolved using the utility corrective action program.

\subsubsection{Vendor/Contractor Oversight}

The utility has a documented program to ensure adequate oversight of vendors/contractors conducting activities involving handling, accounting, and control of SNM.

\subsubsection{Records and Reports}

Records are created and retained, as required by 10 CFR 74.19(a). The accounting records are the basis for the MC\&A program. Quantitative data generated by the utility's calculations of changes in quantities and isotopic composition due to irradiation and decay are recorded and reported in accordance with the utility's standard recording and reporting procedures. The records and reports system includes:

1. An accounting system for maintaining the book inventory

2. Material control records maintained for each ICA

3. Reconciliation of the results of physical inventories to the book inventory

4. Recording the transfer of SNM into or out of each ICA

5. Recording movement of SNM between locations within an ICA, for ICAs where locations have been established

6. Recording the creation of items containing SNM, such as creation of a rod fragment

7. Recording the estimated quantity and origin of SNM that has been inadvertently separated from fuel upon the discovery of the separation

8. Reporting to the accounting group the transfer of SNM into, within, or out of an ICA, if applicable

9. Perpetual inventory records of each ICA, including the serial number or other unique identifier and location of each item in the ICA that contains SNM

10. Historical data of SNM in each nuclear fuel assembly, fuel component, or non-fuel SNM item while in the possession of the utility

11. Retention as required by 10 CFR 72 and 74 .

\subsection{Design Features for MC\&A}

In order to support the MC\&A program described above, the prismatic HTGR and its components will need to incorporate several design features:

- Prismatic fuel elements must include a unique identifier that will remain readable for the life of the fuel element including irradiation in the reactor core. This will make it possible to track the fuel elements as items for the period that the fuel elements are present at the reactor site. This unique identifier should incorporate features to preclude alteration or counterfeiting. Depending upon the credence that NRC is willing to give fuel handling machine records for physical inventory purposes, this unique identifier may need to be "readable" through the stacks of up to 10 layers of fuel elements 
in the reactor core and the used fuel storage area. This may require the development of new technology, such as radio-frequency identification (RFID) tagging and reading.

- The design of the HTGR plant and the unique identifier must include features that permit the unique identifier and fuel element position to be readable remotely in manner that maintains worker exposure as low as reasonably achievable (ALARA) in the reactor core and in fresh and used-fuel storage. (See above.) Because the design of the HTGR reactor core and the used-fuel storage area do not lend themselves to submerging the fuel elements in water to cooling and radiation shielding, special tooling or equipment will be needed to conduct the physical inventory of fuel elements in the reactor core and the used-fuel storage areas. This equipment will need to be able to be remotely operated, for ALARA considerations and to be able to verify the location and unique identifier of prismatic fuel elements. It should also be able to determine, using this or other equipment, whether the fuel elements have been damaged to the extent that SNM may be missing.

- The design of the HTGR plant will need to include provisions (i.e., areas and equipment, such as a hot cell) for handling and packaging severely damaged prismatic fuel elements. This equipment will need to be designed to preclude diversion of SNM from damaged prismatic fuel elements. The packaging for severely damaged prismatic fuel elements (fuel-component containers) needs to be designed so that it can be tamper-safed, permitting it be treated as an item for accountability purposes. The tamper-safing device needs to be rugged so that it will not be damaged in container handling and capable of being remotely read so that it can be inventoried as an item.

- The configuration of the storage area for used prismatic fuel elements and for fuel-component containers must support verification of the storage location and unique identifiers for prismatic fuel elements and containers in manner that maintains worker exposure ALARA. The verification equipment will need to be able to access all storage locations and the storage configuration for the prismatic fuel elements and fuel-component containers must permit the verification equipment to verify the location and unique identifier of each item during inventory.

It is possible that additional design features/equipment will be identified as needed as the design of the fuel-handling system matures and fuel-handling activities become better defined.

\subsection{Flexibility}

Although the NRC requirements discussed in Section 3 permit some flexibility to modify the MC\&A program details to fit plant operations, a program that differed from the essential elements described above would probably not be acceptable to NRC. As discussed in Section 3, the NRC assesses the acceptability of reactor MC\&A programs through its inspection program rather than requiring that the utility submit a Fundamental Nuclear Material Control Plan (FNMCP) document, which is reviewed by $\mathrm{NRC}$, modified in response to NRC requests, and, once approved, implemented by the utility. In this latter case, compliance is assessed by evaluating the conformance of utility procedures and processes with the commitments made in the FNMCP. In the case of nuclear reactors, compliance is assessed by evaluating the conformance of utility procedures and processes with the regulations themselves. In this latter case, the inspectors determine whether the utility procedures and processes adequately implement the regulations and assess whether the utility processes conform with its procedures. 


\section{MC\&A FOR THE PEBBLE-BED HTGR}

\subsection{Introduction}

This section provides a brief description of an MC\&A program suitable for the pebble-bed HTGR likely to meet the NRC requirements and guidance for MC\&A programs discussed in Section 3. The authors recommend early and frequent interaction with NRC during the design process in order to provide assurance that their MC\&A approach will be acceptable to NRC. The following discussion focuses on those aspects of the MC\&A program where the nuclear power plant design can enhance the effectiveness or reduce the operational impact of the MC\&A program.

The MC\&A program for the pebble-bed HTGR will differ from the current MC\&A program for LWRs as discussed in Section 3 because the fuel is in pebble form rather than in the form of item fuel assemblies. The essential elements of that MC\&A program are discussed below.

\subsection{Essential Elements of Pebble-bed HTGR MC\&A Program}

\subsubsection{MC\&A Organization}

Material control functional and organizational relationships are documented in plant directives, instructions, procedures, manuals, or other documents. Documentation includes position qualification requirements and definitions of authority, responsibilities, and duties. The assignment of SNM control and accounting functions is such that the activities of one person or unit serve as an over check and control over the activities of other persons or units. Policies or procedures require that activities involving handling, accounting, or control of SNM by one individual are independently verified by a second person. Responsibilities are assigned in writing for all facets of the SNM control system. Delegation of material control responsibilities and authority are made in writing. Material control functions should be assigned in accordance with 5.2.1.1 through 5.2.1.5. The specific titles are only descriptive-organizations, specific titles, and related job functions may vary. However, the level of organizational authority and control would be expected to be similar to that specified.

\subsubsection{Plant Manager}

The plant manager has overall responsibility for physical control and physical inventory responsibilities for SNM at the plant site.

\subsubsection{SNM/Nuclear Materials Manager}

The SNM/Nuclear Materials manager has overall responsibility for implementation of the SNM control and accounting function. This individual may also have responsibility for nuclear fuel management.

\subsubsection{SNM Custodian}

The SNM custodian at the nuclear power plant is responsible for the performance of the functions that relate to the control of SNM. This individual supervises the material balance area (MBA) custodians. The SNM custodian is responsible for the planning and oversight of the annual physical inventory.

\subsubsection{MBA Custodians}

The MBA custodians are responsible for the items in their item control areas and acknowledge and control transfers of items in and out of their MBAs in writing or by electronic signature. 


\subsubsection{Accountability Group}

The SNM accountability group, which is typically at the plant site but may be centralized, maintains records for the SNM in the plant's possession (as required by 10 CFR 74.19[b]). Members of this group may also perform the fuel burn-up calculations necessary to adjust the SNM inventory to account for fuel irradiation in reactor.

\subsubsection{Policies and Procedures}

The plant prepares and maintains written procedures addressing all aspects of the plant MC\&A program, as required by $10 \mathrm{CFR} 74.19$ (b). These procedures address, as a minimum, the following topics:

1. Organization and personnel responsibilities and authorities

2. Training and qualification requirements for MC\&A personnel

3. Designation and description of MBAs

4. Material control records and reporting

5. Notification for events concerning SNM

6. Receiving and shipping SNM

7. Internal transfer of SNM

8. Physical inventory of SNM

9. SNM element and isotopic calculation method

10. Characterization and identification of items as SNM or non-SNM to preclude loss of control of SNM items

11. Program reviews and corrective actions.

The content and revisions of the MC\&A program and procedures are controlled in writing, by the appropriate plant personnel (e.g., the SNM manager), under the general plant procedures program or specific MC\&A program procedures.

\subsubsection{SNM Receipt and Shipment}

\subsubsection{Review of Fuel Supplier's Values}

The utility or its representative reviews the adequacy of the fuel supplier's MC\&A system used to establish the quantities and assays of SNM in the pebble fuel elements. In the event of a significant discrepancy between the fuel supplier's values for SNM quantities and assays and those determined by the utility, the causes of such discrepancies are investigated with the fuel supplier, and the differences are required to be resolved and reconciled expeditiously.

\subsubsection{Receipt of Fuel/SNM}

For fresh fuel or other SNM received at the plant, the plant:

1. Contacts the shipping vendor in the event the SNM does not arrive as scheduled; initiates an investigation, and determines the reason the shipment has not been received, as required by $10 \mathrm{CFR}$ 73.67 and 10 CFR 74.11

2. Verifies the integrity of the shipping container and tamper-safing devices and resolves any problems identified, as required by 10 CFR 73.67 and 10 CFR 74.11 
3. Verifies that the quantity (container item count/weight) of pebble fuel elements agree with the information on the shipper's documents

4. For non-fuel SNM, verifies that the quantity (item count) of SNM items and their unique identification agree with the information on the shipper's documents

5. Takes appropriate steps to resolve and reconcile any differences in quantities or identification numbers, as required by 10 CFR 73.67 and 10 CFR 74.11

6. Reports the receipt to NRC, as required by 10 CFR 73.67 and 10 CFR 74.11.

\subsubsection{Documentation of Receipt}

The SNM custodian reports the receipt of each fresh fuel container by serial number, or other unique identifier and net weight, to the accounting group. The SNM content of the fuel is calculated based upon factors derived from the review of the supplier's MC\&A program. The receipt of SNM is documented in the material control records and the book inventory updated for the receiving MBA, as required by 10 CFR 74.19(a). A nuclear material transaction report (DOE/NRC Form 741) is completed and submitted to NRC, as required by 10 CFR 74.15 .

\subsubsection{SNM Shipments}

Procedures, required by 10 CFR 74.19(b), provide for:

1. Verification and recording of the serial number or unique identifier of each used fuel storage/shipping cask and the SNM content calculated based upon fuel-element burn-up factors (correlated with measured Cs-137 activity)

2. Recording of the number of pebble-fuel elements and quantities of SNM contained in each used fuel storage/shipping cask

3. For failed fuel, recording the number of failed pebble-fuel elements and estimated quantities of SNM based upon fuel burn-up factors correlated with measured Cs-137 activity) and the weight or size of the failed fuel element contained in each failed-fuel cask

4. Reporting the quantity of SNM shipped, if the quantity is reportable, as required by 10 CFR 74.15

5. Verification of compliance with regulations, including licensing, transportation, and security requirements for shipment

6. Reporting the completion of each shipment to the accounting group.

These procedures address checks to assure that SNM contained in fuel, especially from failed fuel elements, is not shipped inadvertently with shipments of non-fuel SNM waste. Shipping procedures also require that the shipment of fuel assemblies, fuel components, or non-fuel SNM be documented in the material control records and the book inventory updated for the applicable MBA. A nuclear material transaction report (DOE/NRC Form 741) is required to be completed, as mandated by 10 CFR 74.15.

\subsubsection{Review and Audit of Reprocessing (Recycling) Measurements}

Should pebble-bed fuel elements be reprocessed to recover the SNM, the utility or its representative:

1. Reviews the adequacy of the reprocessor's material control system used in establishing the quantities and assays of SNM, including written procedures

2. Audits the implementation of the reprocessor's material control system used in establishing the quantities and assays of SNM, including observation of measurement and material control activities 
3. Audits the reprocessor's accounting activities, measurements, analyses, computations, and records affecting the determination of SNM quantities and assays

4. Review the utility's correlations between the SNM quantities and assays and the Cs-137 activity against the reprocessor's measurements to determine whether the factors being used are appropriate

5. In the event of a significant discrepancy between the reprocessor's values for SNM quantities and assays and those determined by audit, investigates and reconciles any differences expeditiously.

\subsubsection{MC\&A Internal Controls}

The MC\&A program controls pebble-bed fuel elements, new fuel shipping containers, used fuel shipping containers/casks, failed-fuel shipping containers/casks, non-fuel SNM containers, sealed SNM containers, the reactor vessel and fuel feed/discharge equipment, and discrete pieces of SNM (fuel or non-fuel) that are not stored in a container. Each of these units are identified in the material control records by serial number or other unique identifier (e.g., a physical description of the item) and location, as required by 10 CFR 74.19(a).

\subsubsection{Material Balance Areas}

The reactor plant is divided into MBAs for physical and administrative control of SNM. Each MBA is an area with defined physical boundaries so that SNM being moved into or out of the ICA can be measured and identified. Each MBA is under the control of an MBA custodian who maintains records of the items contained within (book inventory, serial numbers/unique identifiers of items and their locations) and transferred in and out of his or her MBA. There are a sufficient number of MBAs to maintain control of the SNM. Typically established as separate MBAs are the new fuel storage area, the reactor vessel and fuel feed/discharge equipment, the storage area for used fuel casks/shipping containers, the storage area for failed-fuel casks/shipping containers and any used fuel storage areas away from the plant (e.g., independent spent fuel storage installations) for which the plant has accountability responsibility, the reactor vessel, and laboratories and other areas housing non-fuel SNM. Appendix B illustrates an MBA layout that was developed for purposes of international safeguards.

\subsubsection{Internal Transfers}

Transfers of SNM into, out of, or within MBAs are made only with written authorization of the SNM custodian or other individual(s) at the plant site responsible for the SNM program. Written authorization is obtained prior to the SNM movement. All transfers of SNM are documented in the MC\&A record system by the responsible persons involved in each operation, and the book inventories are updated for the applicable MBAs. For transfers between MBAs, the shipping MBA custodian and receiving MBA custodian acknowledge the transfers in writing or by electronic signature. Transfers between MBAs are made based upon measured values (fuel-element counts or weight, as appropriate) from which SNM elements and isotopic content can be determined. Documentation of the transfer identifies the quantity of SNM transferred, the shipping MBA and location, the receiving MBA and location, and the authorization for the transfer.

\subsubsection{Physical Inventories}

Physical inventories are conducted at least annually as required by 10 CFR 74.19(c) and according to written inventory procedures, as required by 10 CFR 74.19(b). Physical inventories are conducted in all MBAs and include a determination of the element and isotopic quantity of SNM in the MBA. 


\subsubsection{Fresh Fuel Storage MBA}

For the fresh fuel storage MBA, the physical inventory is accomplished by performing an item count with verification of unique identifier and storage location for sealed fresh fuel storage /shipping containers. The SNM in the sealed containers is determined by the audited shippers' values for unopened containers as discussed in Section 5.2.3.1. For sealed storage containers or storage/shipping containers that have been opened and re-sealed, the SNM measurement is based on the SNM quantity established for the container at the time that it was sealed. The SNM quantity is based on the weight of fuel elements transferred into the storage container or storage/shipping container. At the time that the containers are sealed, the net weight of the pebble-bed fuel elements in the container is attested to by two individuals and recorded along with the calculated SNM quantity.

Unsealed fresh fuel containers are weighed during the physical inventory and the calculated SNM quantity is determined. The weights are compared with the fuel-element count (process data) for fuel elements remaining in the container, and significant discrepancies must be investigated and promptly resolved.

\subsubsection{Used/Failed-fuel Storage MBA(s)}

As used fuel storage/shipping casks are filled, they are weighed and sealed by two individuals. Net weights are compared with the count of pebble-bed fuel elements discharged into the storage/shipping casks to verify that the net weight is consistent with the fuel-element count and significant discrepancies investigated and promptly resolved. The SNM element and isotope quantity is determined by the Cs- 137 and, if applicable, failed fuel-element size correlations for the individual pebble-bed fuel elements and the number of fuel elements discharged to the used fuel or failed-fuel storage/shipping casks. After the fuel storage/shipping casks have been tamper-safed, it is considered an item for inventory purposes. If the contents of a fuel storage/shipping cask are accessed, the contents are re-inventoried, as discussed above, before the container can once again be treated as a single item for inventory purposes. For sealed containers, verification of the tamper-safing is performed as part of the physical inventory.

The physical inventory processes for non-filled fuel storage/shipping casks for used and failed fuel are similar. During the physical inventory, the storage/shipping casks are weighed, and the net weights are compared with the count of pebble-bed fuel elements discharged into the storage/shipping casks to verify that the net weight is consistent with the discharged fuel-element count. Significant discrepancies are investigated and promptly resolved. The SNM element and isotope quantities are determined by the Cs-137 and, if applicable, failed fuel-element size correlations for the individual pebble-bed fuel elements and the number of elements discharged to the used fuel or failed-fuel storage/shipping casks.

\subsubsection{Reactor Vessel and Fuel Feed/Discharge Equipment MBA}

For this MBA, the physical inventory consists of reviewing data from reactor instrumentation (e.g., neutron flux monitors) to verify that the actual core inventory of pebble fuel elements is consistent with the book inventory determined by the number of fuel elements introduced into the fuel feed equipment less the number of fuel elements removed by the fuel discharge equipment. The particular instrumentation monitored depends upon the details of the pebble-bed HTGR design. However, this instrumentation needs to be demonstrated to be capable of detecting significant alterations of the pebble-bed fuel inventory (e.g., $5 \%$ reduction in the total core inventory of fissionable material). ${ }^{\mathrm{d}}$ Significant discrepancies between the book inventory and the reactor instrumentation data are promptly resolved. If the physical inventory measurements for this MBA are consistent with the book inventory, the physical inventory value is the

d. The nominal core inventory is $107 \mathrm{~kg}$ of fissionable material. Detection of a $5 \%$ discrepancy would correspond to detection of the loss of $5.35 \mathrm{~kg}$ of $\mathrm{U}-235 / \mathrm{Pu}$. This is consistent with a detection goal of $95 \%$ probability of detecting the loss of $9 \mathrm{~kg}$ of U-235, as discussed in Section 3. 
book inventory. The SNM content of the pebble fuel is calculated based upon the equilibrium fuel burnup or the actual fuel burnup if operations, during the inventory period, would create a fuel element burnup that significantly differed from the equilibrium value.

Should the reactor need to be shut down and the vessel opened, additional measurements (e.g., in-core measurements of pebble-fuel volume) will be made to verify that the actual core inventory of pebble-fuel elements is consistent with the book inventory. Significant discrepancies between the book inventory and the reactor instrumentation data will be promptly resolved.

\subsubsection{Physical Inventory of Non-fuel SNM}

For non-fuel SNM, the method of physical inventory depends on the method of storage and use:

1. For installed components, verification is performed at the time of installation, and administrative procedures and controls are established so that records concerning the location and unique identity are accurate.

2. For non-installed components stored in primary containment, administrative procedures and controls are established so that records concerning the location and unique identity are accurate when the reactor is at power, and verification is performed during refueling outages.

3. For non-fuel SNM containers, the physical inventory is performed by item count of the containers. If the contents of the container are accessed, procedures require that the contents be physically reinventoried or administrative procedures be in place to ensure the integrity of the contents before the container can be treated as a single item for inventory purposes.

\subsubsection{Reconciliation of Physical and Book Inventories and Resolution of Discrepancies}

The physical inventory results are reconciled to the book inventory. Discrepancies between the physical inventory and the book inventory are required to be investigated and resolved expeditiously. Once discrepancies are resolved, the book inventory is adjusted to agree with the result of the physical inventory. Procedures require that the results of the physical inventory of SNM be documented in the material control records of the applicable MBA and employed as input to the isotopic calculations. The inventory results are documented on a Material Balance Report (DOE/NRC Form 742) and Physical Inventory Listing (DOE/NRC Form 742C), as required by 10 CFR 74.13.

\subsubsection{SNM Calculations}

\subsubsection{Element and Isotopic Computations}

Methods of computation are established and used for determining the total element and isotopic composition of SNM in irradiated pebble-bed fuel elements and failed fuel elements. It is anticipated that these will be based upon the Cs-137 activity correlations that the utility employs to identify irradiated pebble-bed fuel elements for removal from the reactor core. However, prior to startup of plant operations, the utility will perform sufficient research on irradiated pebble-bed fuel to establish the correlation between Cs-137 activity and the pebble-bed fuel SNM element quantities and isotopic assays to determine correlation factors and the associated uncertainties. If these uncertainties are so large that a limit of error on an inventory difference of 9 kilograms or less U-235 for the material balance around the utility's annual inventory cannot be achieved, additional measurement systems and methods or more frequent inventories will be established to obtain this level of material accounting accuracy. The computed values derived by this method are the basis for shipment documents, as required by 10 CFR 74.15, and material status reports, as required by 10 CFR 74.13. 


\subsubsection{Refinement of Calculation Methods}

Procedures require that refining the element and isotopic computations used in determining the SNM content of irradiated pebble-bed fuel elements and failed fuel elements be considered as new technologies evolve or new information becomes available. For reprocessed used fuel or recovered failed fuel, this may include a collection and comparison of reprocessing-plant measurement data with computed data for pebble-bed fuel elements or failed fuel elements, as appropriate.

\subsubsection{System Review and Assessment}

Procedures require periodic - typically annual and no less frequently than triennial—reviews of the MC\&A program. The reviews are conducted, and the results are documented and reported in accordance with the requirements of the utility's quality assurance or self-assessment program. Discrepancies or program deficiencies are documented, investigated, and reported, as required by 10 CFR 74.11 and 10 CFR 20.2201, and resolved using the utility corrective action program.

\subsubsection{Vendor/Contractor Oversight}

The utility has a documented program to ensure adequate oversight of vendors/contractors conducting activities involving handling, accounting, and control of SNM.

\subsubsection{Records and Reports}

Records are created and retained, as required by 10 CFR 74.19(a). The accounting records are the basis for the MC\&A program. Quantitative data generated by the utility's calculations of changes in quantities and isotopic composition due to irradiation and decay are recorded and reported in accordance with the utility's standard recording and reporting procedures. The records and reports system includes:

1. An accounting system for maintaining the book inventory

2. Material control records maintained for each MBA

3. Reconciliation of the results of physical inventories to the book inventory

4. Recording the transfer of SNM into or out of each MBA

5. Recording movement of SNM between locations within an MBA for MBAs where locations have been established

6. Recording the estimated quantity of SNM in failed fuel elements discharged from the reactor to the failed-fuel storage cask/shipping container

7. Reporting to the accounting group the transfer of SNM into, within, or out of an MBA, if applicable

8. Perpetual inventory records of each MBA, including the serial number or other unique identifier and location of each item in the MBA that contains SNM and the measured values of SNM, obtained as described above for SNM not in item form

9. Retention as required by 10 CFR 72 and 74 .

\subsection{Design Features for MC\&A}

In order to support the MC\&A program described above, the design must include a number of features in addition to the usual complement of MC\&A provisions:

- Capability to measure burnup of pebbles for purposes of recycling discrimination, for accountability measurements for used fuel discharged to storage/shipping casks, and for failed fuel. Cs-137 and Cs- 
137 to Cs-134 ratio measurement technology is well known. Other methods may be possible or preferred. $^{33}$

- The design must include data processing equipment that links fuel-burnup measurements to the fate of the measured fuel elements (e.g., whether the element is discharged as used, discharged as failed, or returned to the reactor).

- The design must also support additional measures for failed fuel (e.g., largest dimension) to make it possible to distinguish between low burnup failed fuel and high burnup partial pebble fuel elements.

- The design must support accountability measurements of the mass of fresh, used, and failed pebble fuel elements in their storage/shipping containers or casks. The design development must include research to correlate the Cs-137/fuel burnup surrogate accountability measurements with fissile material type (i.e., $\mathrm{U}$ or $\mathrm{Pu}$ ), quantity, and $\mathrm{U}$ isotopic composition.

- In addition, the development of the MC\&A program and the demonstration of its acceptability to NRC may require the development of additional reactor-core instrumentation or other accountability measures for the physical inventory of the reactor vessel and fuel feed/discharge equipment MBA.

- The design should support measurement of the inventory of used fuel in the used-fuel storage vessels; this could be achieved through the incorporation of instrument tubes running the length of the vessels through which level probes could be inserted.

- The design of the fresh, used, and failed pebble-fuel elements storage/shipping containers or casks must include a unique identifier that will remain readable for the life of the casks/containers. The design of the unique identifier must be readable remotely in manner that maintains worker exposure ALARA for the used and failed-fuel storage areas.

- The configuration of the storage area for used and failed pebble-fuel elements must support verification of unique identifiers for the containers/casks and the verification of the storage locations for these items in manner that maintains worker exposure ALARA.

- Any nuclear material containers or storage spaces intended to be considered as items for accountancy purposes (e.g. fresh fuel shipment canisters) should include provisions for practical installation of tamper-safing devices. In the event the facility is selected for international safeguards, this provision should also include accommodation of IAEA tamper-indicating devices.

\subsection{Flexibility}

The NRC requirements discussed in Section 3 permit some flexibility to modify the MC\&A program details to fit plant operations. The MC\&A program essential elements described above would probably be acceptable to NRC. However, additional accountability measures, particularly addressing the physical inventory of the reactor vessel and fuel feed/discharge equipment MBA, may be required for an MC\&A program acceptable to the NRC. As discussed in Section 3, the NRC assesses the acceptability of reactor MC\&A programs through its inspection program rather than requiring that the utility submit a FNMCP document, which is reviewed by NRC, modified in response to NRC requests, and, once approved, implemented by the utility. In this particular case, compliance is assessed by evaluating the conformance of utility procedures and processes with the commitments made in the FNMCP. In the case of nuclear reactors, compliance is assessed by evaluating the conformance of utility procedures and processes with the regulations themselves. In this latter case, the inspectors determine whether the utility procedures and processes adequately implement the regulations as well as assess the conformance of the utility processes with its procedures. 


\section{REFERENCES}

1. World Nuclear Association, "U.S. Nuclear Power Policy," http://www.worldnuclear.org/info/inf41_US_nuclear_power_policy.html, updated August 2011.

2. 10 CFR Part 50 (NRC-2008-0237), 2008, "Policy Statement on the Regulation of Advanced Reactors," Federal Register, Vol. 73, No. 199.

3. Stein, M., et al., 2009, "Safeguards by Design - An Industrial Approach," Proceedings of Global 2009 Conference, Paris, France, September, 2009.

4. IAEA Safeguards Technical Report STR-360, 2009, Facility Design and Plant Operation Features that Facilitate the Implementation of IAEA Safeguards, IAEA, Vienna, Austria, February 2009.

5. Bjornard, T., et al., 2009, "Institutionalizing Safeguards-by-Design: High-Level Framework," INL/EXT-14777 Rev. 1, February, 2009.

6. Durst, P.C., and T. Bjornard, 2010, "Safeguards Guidance Document for Designers of Commercial Nuclear Facilities: International Nuclear Safeguards Requirements and Practices for High Temperature Gas Reactors with Pebble Fuel (Draft)", INL/EXT-10-18438 Rev. 0, May 2010.

7. Durst, P.C. and T. Bjornard, 2010, "Safeguards Guidance Document for Designers of Commercial Nuclear Facilities: International Nuclear Safeguards Requirements and Practices for High Temperature Gas Reactors with Prismatic Fuel (Draft)," INL/EXT-10-17981 Rev. 0, May 2010.

8. 72 FR 12705, 10 CFR 73, Design Basis Threat, Final Rule, US Nuclear Regulatory Commission, Washington DC 20555

9. United States Government Accountability Office, 2006, Nuclear Power Plants - Efforts Made to Upgrade Security, but the Nuclear Regulatory Commission's Design Basis Threat Process Should Be Improved, Report to the Chairman, Subcommittee on National Security, Emerging Threats, and International Relations, March 2006.

10. Nuclear Energy Institute Press Release, 2004, “All Nuclear Power Plants Meet NRC Deadline for Security Enhancements," October 28, 2004.

11. IAEA, 2011, "The Use of Nuclear Material Accountancy and Control for Nuclear Security at Facilities," IAEA Nuclear Security Series Technical Guide, DRAFT, August 28, 2011.

12. Bjornard, T., et al., 2010, Implementing Safeguards-by-Design, INL/EXT-09-17085, February 2010.

13. Bjornard, T., et al., 2009, "Improving the Safeguardability of Nuclear Facilities," Second International Meeting on Next Generation Safeguards, Tokai, Japan, October 26-28, 2009.

14. Bjornard, T., et al., "Safeguards-by-Design: Early Integration of Physical Protection and Safeguardability into Design of Nuclear Facilities," Proceedings of Global 2009 Conference, Paris, France, September 9, 2009.

15. Bjornard, T., et al., 2010, Security by Design - Critical Enablers, Core Principles, and Best Practices, INL/EXT-10-19465, October 2010.

16. Cipiti, B., and F. Duran, 2009, Integrated Safeguards and Security for Material Protection, Accounting and Control, Sandia Report SAND2009-xxxx, October 2009.

17. WINS International Best Practice Guide, 2010, "Security by Design, Rev 1.0," World Institute for Nuclear Security.

18. Slabber, J., 2004, "PBMR Nuclear Material Safeguards," $2^{\text {nd }}$ International Topical Meeting on High Temperature Reactor Technology, Beijing, China, September 22-24, 2004. 
19. NGNP Fuel Qualification White Paper, INL/EXT-10-18610, Rev 0, July 2010.

20. "Next Generation Nuclear Plant - Pre-Conceptual Design Report," INL/EXT-07-12967, September 2007.

21. General Atomics, "Next Generation Nuclear Plant (NGNP) Prismatic HTGR Conceptual Design Report,” NGNP-S00218, Revision 0, December 23, 2010.

22. SECY-08-005, 2008, Results of Material Control and Accounting Baseline Inspections Conducted at Nuclear Power Reactors and Wet Storage Sites, U.S. Nuclear Regulatory Commission, Washington DC, January 2008.

23. Altman, W., J. Hockert, and E. Quinn, 1980, A Safeguards Case Study of the Nuclear Materials and Equipment Corporation Uranium Processing Plant Apollo, Pennsylvania, NUREG-0627, U.S. Nuclear Regulatory Commission, Washington DC, March 1980.

24. Millstone Unit1 Fuel Accountability Project Final Report, Northeast Utility System, available from the NRC Public Document Room (Access no. ML012850396), Washington, DC, October 2001.

25. OIG-03-A-15, 2003, Audit of NRC's Regulatory Oversight of Special Nuclear Materials, Office of the Inspector General, U.S. Nuclear Regulatory Commission, Washington DC, May 2003.

26. GAO-05-339, 2005, "NRC Needs to Do More to Ensure that Power Plants Are Effectively Controlling Spent Nuclear Fuel," U.S. Government Accountability Office, Washington DC, April 2005.

27. U.S. Federal Register, U.S. Government Printing Office, 1998, 63 FR 2426 Regulatory Guides; Withdrawal, http://www.gpo.gov/fdsys/pkg/FR-1998-01-15/pdf/98-1047.pdf, January 15, 1998.

28. Regulatory Guide 5.29, 1975, Nuclear Material Control Systems for Nuclear Power Plants, Rev.1 (Withdrawn), http://pbadupws.nrc.gov/docs/ML0037/ML003740073.pdf., U.S. Nuclear Regulatory Commission, Washington DC, June 1975.

29. ANSI N15.8-2009, Material Control Systems - Special Nuclear Material Control and Accounting Systems for Nuclear Power Plants, American National Standards Institute, New York, NY, February 2009.

30. Title 10 Code of Regulations, Part 74, 2011, U.S. Government Printing Office, http://www.nrc.gov/reading-rm/doc-collections/cfr/part074/full-text.html, June 2011.

31. Gitau, E. Travis, and William S. Charlton, 2011, Safeguards System Development for a PebbleFueled HTGR, Presented at the $52^{\text {nd }}$ Annual Meeting of the Institute of Nuclear Materials Management, http://www.inmm.org/source/proceedings/files/2011/a456 1.pdf, July 2011.

32. NUREG-1065, 1995, Acceptable Standard Format and Content for the Fundamental Nuclear Material Control (FNMC) Plan Required for Low Enriched Uranium Facilities, Revision 2, U.S. Nuclear Regulatory Commission, Washington, DC, December 1995.

33. Los Alamos National Laboratory, "Panda Nondestructive Assay Manual," http://www.lanl.gov/orgs/n/n1/panda/index.shtml. 


\section{Appendix A}

\section{NRC MC\&A Regulations for Nuclear Power Reactors}




\section{Appendix A}

\section{NRC MC\&A Regulations for Nuclear Power Reactors}

\section{CFR 74 Requirements Applicable to Nuclear Power Reactors}

\section{$\S 74.11$ Reports of loss or theft or attempted theft or unauthorized production of special nuclear material.}

(a) Each licensee who possesses one gram or more of contained uranium-235, uranium-233, or plutonium shall notify the NRC Operations Center within 1 hour of discovery of any loss or theft or other unlawful diversion of special nuclear material which the licensee is licensed to possess, or any incident in which an attempt has been made to commit a theft or unlawful diversion of special nuclear material. The requirement to report within 1 hour of discovery does not pertain to measured quantities of special nuclear material disposed of as discards or inventory difference quantities....

(b) This notification must be made to the NRC Operations Center via the Emergency Notification System if the licensee is party to that system. If the Emergency Notification System is inoperative or unavailable, the licensee shall make the required notification via commercial telephonic service or other dedicated telephonic system or any other method that will ensure that a report is received by the NRC Operations Center within one hour. The exemption of $\S 73.21(\mathrm{~g})(3)$ applies to all telephonic reports required by this section.

(c) Reports required under $\S 73.71$ need not be duplicated under requirements of this section.

\section{$\S 74.13$ Material status reports.}

(a) Each licensee, including nuclear reactor licensees as defined in $\S \S 50.21$ and 50.22 of this chapter, possessing, or who had possessed in the previous reporting period, at any one time and location, special nuclear material in a quantity totaling one gram or more of contained uranium-235, uranium233, or plutonium shall complete and submit, in computer-readable format Material Balance Reports concerning special nuclear material that the licensee has received, produced, possessed, transferred, consumed, disposed, or lost. This prescribed computer-readable report replaces the DOE/NRC form 742 which has been previously submitted in paper form. The Physical Inventory Listing Report must be submitted with each Material Balance Report. This prescribed computer-readable report replaces the DOE/NRC Form $742 \mathrm{C}$ which has been previously submitted in paper form. Reports must be submitted for each Reporting Identification Symbol (RIS) account including all holding accounts. Each licensee shall prepare and submit the reports described in this paragraph as specified in the instructions in NUREG/BR-0007 and NMMSS Report D-24 "Personal Computer Data Input for NRC Licensees."Copies of these instructions may be obtained from the U.S. Nuclear Regulatory Commission, Division of Fuel Cycle Safety and Safeguards, Washington, DC 205550001, or by e-mail to RidsNmssFcss@nrc.gov.... Licensees subject to the requirements of $\S \S$ 74.19 (c), ... shall submit a report within 60 calendar days of the beginning of the physical inventory. All other licensees shall submit a report no later than March 31 of each year. The Commission may permit a licensee to submit the reports at other times for good cause. Each licensee required to report material balance, and inventory information, as detailed in this part, shall resolve any discrepancies identified during the report review and reconciliation process within 30 calendar days of notification of a discrepancy identified by NRC. 
(b) Any licensee who is required to submit routine Material Status Reports pursuant to $\S 75.35$ of this chapter (pertaining to implementation of the US/IAEA Safeguards Agreement) shall prepare and submit these reports only as provided in that section (instead of as provided in paragraph (a) of this section).

\section{§ 74.15 Nuclear material transaction reports.}

(a) Each licensee who transfers or receives special nuclear material in a quantity of one gram or more of contained uranium-235, uranium-233, or plutonium shall complete in computer-readable format a Nuclear Material Transaction Report. In addition, each licensee who adjusts the inventory in any manner, other than for transfers and receipts, shall submit a Nuclear Material Transaction Report, in computer-readable format, to coincide with the submission of the Material Balance report. This shall be done as specified in the instructions in NUREG/BR-0006 and NMMSS Report D-24, "Personal Computer Data Input for NRC Licensees." Copies of these instructions NUREG/BR-0006 and NMMSS Report D-24, "Personal Computer Data Input for NRC Licensees" may be obtained either by writing the U.S. Nuclear Regulatory Commission, Division of Fuel Cycle Safety and Safeguards, Washington, DC 20555-0001, or by e-mail to RidsNmssFcss@nrc.gov. Each licensee who transfers the material shall submit a Nuclear Material Transaction Report in computer-readable format as specified in the instructions no later than the close of business the next working day. Each licensee who receives the material shall submit a Nuclear Material Transaction Report in computer-readable format in accordance with instructions within ten (10) days after the material is received. This prescribed computer-readable format replaces the DOE/NRC Form 741 which has been previously submitted in paper form.

(b) Each licensee who receives 1 gram or more of contained uranium-235, uranium-233, or plutonium from a foreign source shall:

(1) Complete in computer-readable format both the supplier's and receiver's portion of the Nuclear Material Transaction Report;

(2) Perform independent tests to assure the accurate identification and measurement of the material received, including its weight and enrichment; and

(3) Indicate the results of these tests on the receiver's portion of the form.

(c) Each licensee who ships special nuclear material in a quantity of one gram or more of contained uranium-235, uranium-233, or plutonium to foreign recipient shall complete in computer-readable format the supplier's portion of the Nuclear Material Transaction Report. The licensee shall complete the receiver's portion of the Nuclear Material Transaction Report only if a significant shipperreceiver difference as described in $\S \S 74.31,74.43$, or 74.59 , as applicable, is identified.

(d) Any licensee who is required to submit inventory change reports pursuant to $\S 75.34$ of this chapter (pertaining to implementation of the US/International Atomic Energy Agency (IAEA) Safeguards Agreement) shall prepare and submit these reports only as provided in that section (instead of as provided in paragraphs (a) and (b) of this section).

\section{§ 74.19 Recordkeeping.}

(a) Licensees subject to the recordkeeping requirements of $\S \S 74.31,74.33,74.43$, or 74.59 of this part are exempt from the requirements of paragraphs (a)(1) through (4) of this section. Otherwise:

(1) Each licensee shall keep records showing the receipt, inventory (including location and unique identity), acquisition, transfer, and disposal of all special nuclear material in its possession regardless of its origin or method of acquisition.

(2) Each record relating to material control or material accounting that is required by the regulations in this chapter or by license condition must be maintained and retained for the period specified by the appropriate regulation or license condition. If a retention period is not 
otherwise specified by regulation or license condition, the licensee shall retain the record until the Commission terminates the license that authorizes the activity that is subject to the recordkeeping requirement.

(3) Each record of receipt, acquisition, or physical inventory of special nuclear material that must be maintained pursuant to paragraph (a)(1) of this section must be retained as long as the licensee retains possession of the material and for 3 years following transfer or disposal of the material.

(4) Each record of transfer of special nuclear material to other persons must be retained by the licensee who transferred the material until the Commission terminates the license authorizing the licensee's possession of the material.

(b) Each licensee that is authorized to possess special nuclear material in a quantity exceeding one effective kilogram at any one time shall establish, maintain, and follow written material control and accounting procedures that are sufficient to enable the licensee to account for the special nuclear material in its possession under license. The licensee shall retain these procedures until the Commission terminates the license that authorizes possession of the material and retain any superseded portion of the procedures for 3 years after the portion is superseded.

(c) Other than licensees subject to $\S \S 74.31,74.33,74.41$, or 74.51 , each licensee who is authorized to possess special nuclear material, at any one time and site location, in a quantity greater than 350 grams of contained uranium-235, uranium-233, or plutonium, or any combination thereof, shall conduct a physical inventory of all special nuclear material in its possession under license at intervals not to exceed 12 months. The results of these physical inventories need not be reported to the Commission, but the licensee shall retain the records associated with each physical inventory until the Commission terminates the license that authorized the possession of special nuclear material.

(d) Records that must be maintained pursuant to this part may be the original or a reproduced copy or a microform if the reproduced copy or microform is duly authenticated by authorized personnel and the microform is capable of producing a clear and legible copy after storage for the period specified by Commission regulations. The record may also be stored in electronic media with the capability for producing legible, accurate, and complete records during the required retention period. Records such as letters, drawings, or specifications must include all pertinent information such as stamps, initials, and signatures. The licensee shall maintain adequate safeguards against tampering with and loss of records.

\section{Subpart F--Enforcement}

\section{§ 74.81 Inspections.}

(a) Each licensee shall afford to the Commission at all reasonable times opportunity to inspect special nuclear material and the premises and facilities wherein special nuclear material is used, produced, or stored.

(b) Each licensee shall make available to the Commission for inspection, upon reasonable notice, records kept by the licensee pertaining to its receipt, possession, use, acquisition, import, export, or transfer of special nuclear material....

(c)(3) The licensee shall afford any NRC resident inspector assigned to their site, or other NRC inspectors identified by the Director of the Office of Nuclear Material Safety and Safeguards as likely to inspect the facility, immediate unfettered access, equivalent to access provided regular plant employees, following proper identification and compliance with applicable access control measures for security, radiological protection, and personal safety. 


\section{$\S 74.82$ Tests.}

Each licensee shall perform, or permit the Commission to perform, any tests that the Commission deems appropriate or necessary for the administration of the regulations in this part, including tests of:

(a) Special nuclear material;

(b) Facilities where special nuclear material is utilized, produced, or stored; and

(c) Other equipment and devices used in connection with the production, utilization, or storage of special nuclear material.

\section{§ 74.83 Violations.}

(a) The Commission may obtain an injunction or other court order to prevent a violation of the provisions of--

(1) The Atomic Energy Act of 1954, as amended;

(2) Title II of the Energy Reorganization Act of 1974, as amended; or

(3) A regulation or order issued pursuant to those Acts.

(b) The Commission may obtain a court order for the payment of a civil penalty imposed under section 234 of the Atomic Energy Act:

(1) For violations of--

(i) Sections 53, 57, 62, 63, 81, 82, 101, 103, 104, 107, or 109 of the Atomic Energy Act of 1954, as amended;

(ii) Section 206 of the Energy Reorganization Act;

(iii) Any rule, regulation, or order issued pursuant to the sections specified in paragraph (b)(1)(i) of this section;

(iv) Any term, condition, or limitation of any license issued under the sections specified in paragraph (b) (1)(i) of this section.

(2) For any violation for which a license may be revoked under section 186 of the Atomic Energy Act of 1954, as amended.

\section{$\S 74.84$ Criminal penalties.}

(a) Section 223 of the Atomic Energy Act of 1954, as amended, provides for criminal sanctions for willful violation of, attempted violation of, or conspiracy to violate, any regulation issued under sections $161 \mathrm{~b}, 161 \mathrm{i}$, or $161 \mathrm{o}$ of the Act. For purposes of section 223, all the regulations in part 74 are issued under one or more of sections $161 \mathrm{~b}, 161 \mathrm{i}$, or $161 \mathrm{o}$, except for the sections listed in paragraph (b) of this section.

(b) The regulations in part 74 that are not issued under sections $161 \mathrm{~b}, 161 \mathrm{i}$, or $161 \mathrm{o}$ for the purposes of section 223 are as follows: $\S \S 74.1,74.2,74.4,74.5,74.6,74.7,74.8,74.83$ and 74.84.

\section{Notes for interpretation of 10 CFR 74.}

- The term "person licensed under this chapter" as used in 10 CFR 74 means a licensee under 10 CFR Part 70 (Atomic Energy Act of 1954, as amended, Section 53 licenses [42 USC 2153]). (See 10 CFR § 74.1(b).) Because nuclear power plant licenses are issued pursuant to 10 CFR 50 (Production and Utilization Facilities, Atomic Energy Act Section 103 [power reactors] and 104 [research reactors] licenses), they are not included in the category of "persons licensed under this chapter." Note that, although enrichment plants are production facilities under the Atomic Energy Act of 1954, as amended (Section 11(v) 42 USC 2111), they are licensed under 10CFR 
70. Thus enrichment facilities are licensed under this chapter. Were a reprocessing plant to be licensed, it would be expected to be licensed under 10 CFR 50 (See 10 CFR $\S 50.2$ ). Thus, the 10 CFR 74 requirements would not be applicable without a rule change. (See also the reprocessing plant exceptions in $10 \mathrm{CFR} \S 74.41$ (a) and $10 \mathrm{CFR} \S 74.51(\mathrm{a})$.)

- Because nuclear power reactors are in the category "utilization facilities," (See 10CFR $\S 50.2$ ) regulatory requirements that exclude "production and utilization facilities" do not apply to power reactors. 
Appendix B

\section{International Safeguards MBA Layouts for HTGRs}




\section{Appendix B}

\section{International Safeguards MBA Layouts for HTGRs}

\section{A Typical High Temperature Gas Reactor}

Material Balance Area (MBA) Layout With Key Measurement Points (KMPs)

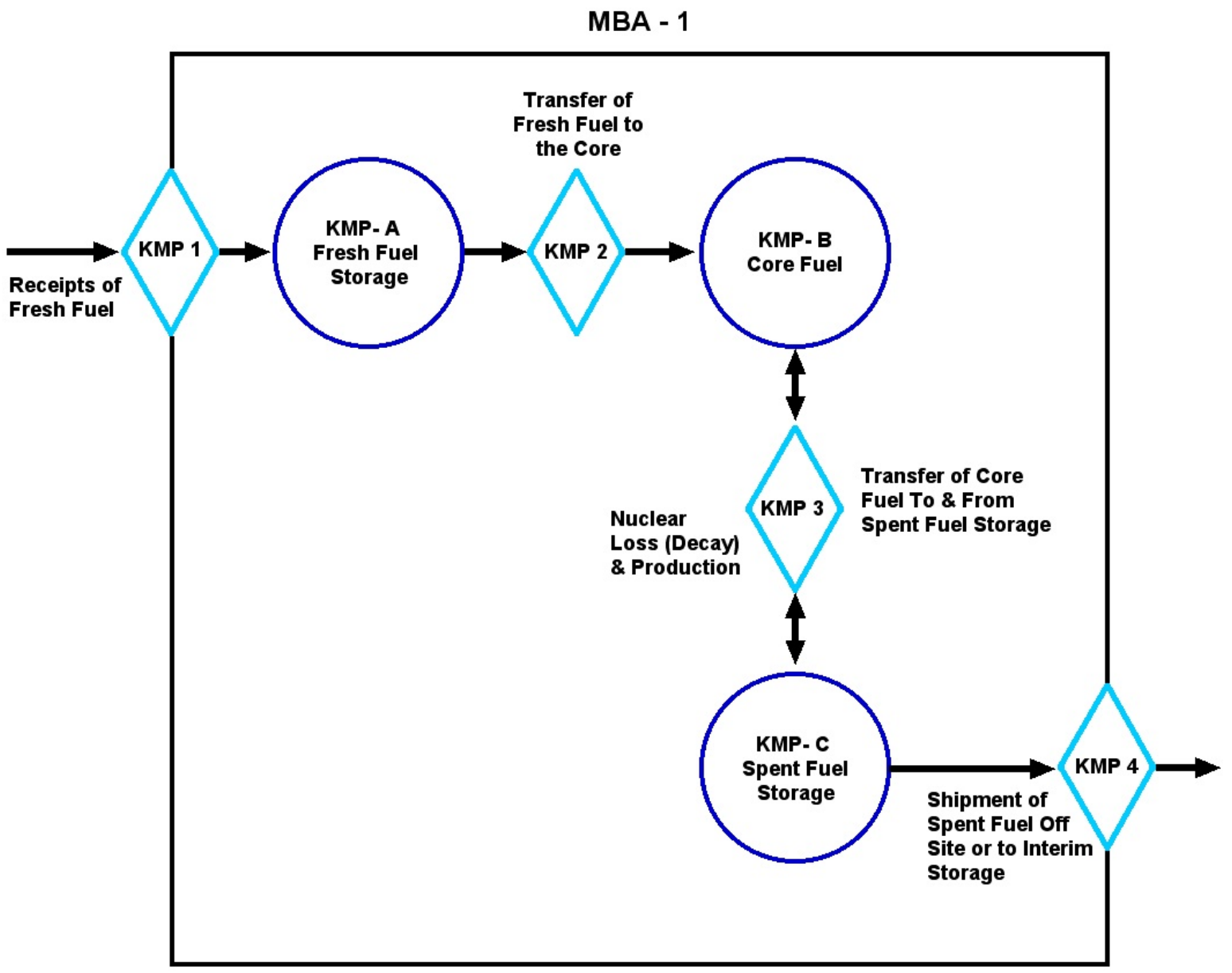

Figure B-1. Material balance area layout for a prismatic fuel HTGR. ${ }^{6}$ 


\section{A Typical Pebble Fuel High Temperature Gas Reactor \\ Material Balance Area With Key Measurement Points (KMPs)}

MBA - 1

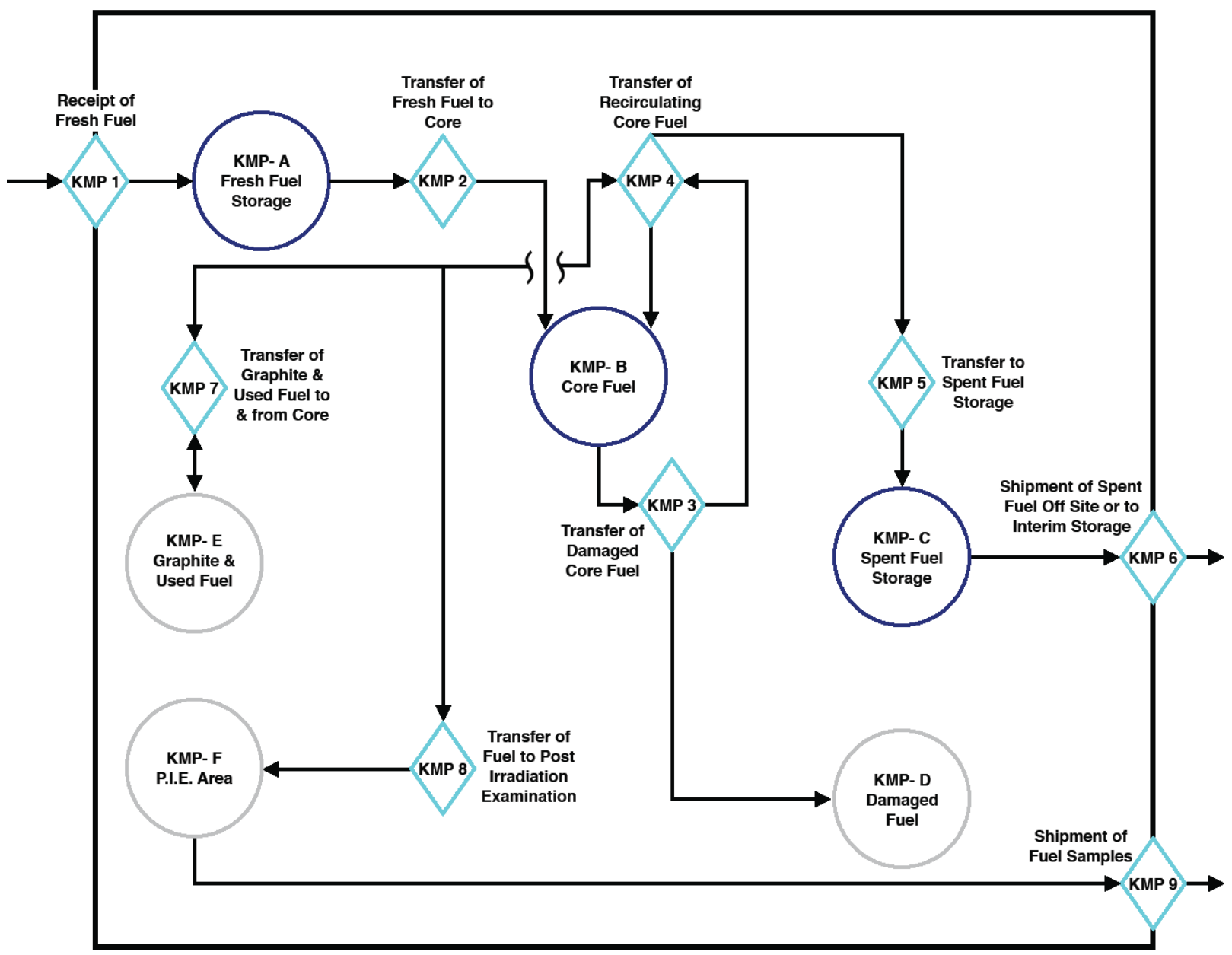

Figure B-2. Material balance area layout for pebble-fuel HTGR. ${ }^{7}$ 